\title{
Mahalli İdarelerde Altyapı Yatırımlarının Finansman Yöntemleri: Ankara Su ve Kanalizasyon İdaresi (ASKİ) Genel Müdürlüğü Örneği
}

\author{
Financial Instruments of Infrastructure Investments in Local Administrations: The \\ Case of Ankara Water and Sewerage Administration (ASKI) General Directorate
}

\author{
Doç. Dr. Mustafa TUNA (iD ${ }^{1}$, Sevilay BOSTANCI (iD)2
}

\begin{abstract}
Öz
Mahalli idarelerin öncelikle belediye yasaları olmak üzere çeşitli kanun ve diğer mevzuatla birçok görevleri bulunmaktadır. $\mathrm{Bu}$ doğrultuda, üstlendikleri hizmetleri yerine getirilebilmek için mahalli idarelere yasalarla birtakım gelirler tahsis edilmiştir. Birçok gelir kaynaklarına rağmen mahalli idare gelirlerinin yeterli olduğunu söylemek mümkün değildir. Kentleşme süreciyle birlikte, halkın bu idarelerden beklentileri de artmış ve çeşitlenmiştir. Bu süreçte yörenin kalkınmasının kilit noktası durumundaki mahalli idareler, yöreye ilişkin yüksek maliyetli altyapı ve diğer yatırımlar nedeniyle yoğun kaynak ihtiyacına gereksinim duymaya başlamışlardır. Türkiye'de merkezi idare son yıllarda yeni altyapı yatırımlarının finansmanı için alternatif ve yeni finansman teknikleri geliştirmeye başlamıştır. Yasal olarak yapılması gerekli yeni düzenlemelerle mahalli idarelerde hali hazırdaki ve yeni yatırımların finansmanında, merkezi idarenin uygulayacağı yeni finansman tekniklerini uygulanabilir hale gelecektir. Mahalli idarelerin uygulamalarında bazı farklılıklar olsa da merkezi idare ile benzer finansman tekniklerini kullanmaktadırlar. Bunlar; finansman şirketleri ile yapılan özel uygulamalar ve özel sektör şirketleriyle yapılan sözleşmelere dayanan özel imtiyazlar, sermaye piyasası araçları ile finansman şeklinde özetlenebilir. Seçilmiş ülke örneklerinde olduğu gibi, Türkiye'de de son yıllarda altyapı yatırımları alanında bazı yasal düzenlemeler yapılarak alternatif finansman yöntemlerinin kullanılmasına olanak sağlandığı görülmektedir. Literatür taraması, ikincil veriler ile örnek olarak incelenen kurumun yatırım kaynaklarının analiz sonuçlarına göre yerel yönetimlerde sermaye piyasası araçlarının kullanım olanaklarının geliştirilmesinin zorunlu olduğu ortaya çıkmaktadır.
\end{abstract}

Anahtar Kelimeler: Mahalli idareler, altyapı yatırımları, finansman yöntemleri, yatırım finansmanı, yerel ve kamusal ihtiyaç analizi, sermaye piyasası araçları, Ankara Su ve Kanalizasyon İdaresi Genel Müdürlüğü

Makale Türü: Araştırma

\begin{abstract}
Local administrations have many duties regulated by various laws and other legislation, including mainly municipal laws. Accordingly, defined revenues are allocated to local administrations to fulfill services they have undertaken. Despite many sources of income, it isn't possible to state that local governments' revenues are sufficient. The expectations from local administrations have increased and diversified with urbanization. Local administrations begin to need higher resources for higher cost of infrastructure and other investments. In recent years, the Turkish central administration has begun to develop alternative and new financial models for infrastructure investments. New regulation adjustments are necessary for new financial models of central administration, to be applicable in financing of existing and new investments in local administrations. Although there are some differences in the practices of local administrations, they use similar financing techniques as central administration. These can be summarized as; special concessions based on private practices with financing companies and contracts with private sector companies financing through capital market instruments. There are also some examples of alternative financial models in Turkey. According to the literature review, secondary data and analysis results of the
\end{abstract}

\footnotetext{
${ }^{1}$ Ankara Üniversitesi, Uygulamalı Bilimler Fakültesi, Gayrimenkul Geliştirme ve Yönetimi Bölümü, mtuna57@gmail.com

${ }^{2}$ Ankara Üniversitesi, Fen Bilimleri Enstitüsü, Gayrimenkul Geliştirme ve Yönetimi Bölümü, svlybstnc@gmail.com
} 
Tuna ve Bostancı / Mahalli İdarelerde Altyapı Yatırımlarının Finansman Yöntemleri: Ankara Su ve Kanalizasyon İdaresi (ASKİ) Genel Müdürlüğü Örneği / Financial Instruments of Infrastructure Investments in Local Administrations: The Case of Ankara Water and Sewerage Administration (ASKI) General Directorate

investment resources of Ankara Water and Sewerage Administration has been examined in this study. It is revealed that it is necessary to improve the utilization opportunities of capital market instruments in local governments.

Keywords: Local governments, infrastructure investments, financial models, investment finance, local and public needs analysis and capital market instruments, Ankara Water and Sewerage Administration

Paper Type: Research

\section{Giriş}

Mahalli idareler; sınırları belirlenmiş olan coğrafi yerleşim alanı içerisinde yaşamını devam ettiren yerel halkın mahalli ve müşterek ihtiyaçlarına cevap vermek amacıyla kurulan, yetkileri kanunlarla sınırlandırılmış, mali ve idari özerkliği bulunan, merkezi yönetimden ayrı tüzel yapısı bulunan anayasal kuruluşlardır. Sundukları hizmetlerin yanında ayrıca demokrasinin gelişmesi bağlamında da önemli rollere sahip olan mahalli idarelerin önemi her geçen gün artmaktadır. Kentlere göçlerin sonucunda nüfusun ve şehirleşmenin artış göstermesi ile birlikte mahalli idarelerin vatandaşlara sundukları hizmetlerin sayısı ve niteliğinde artış olmuştur. Mahalli idarelerin etkin hizmet sunmaları, mali kaynakları, kaynaklarını verimli kullanmaları, kapasiteleri ve mali özerklikleri gibi konular, 1980'li yıllardan itibaren oluşan iktisadi, siyasi, mali ve idari gelişmelerin sonucunda Türkiye de dâhil olmak üzere dünyadaki diğer ülkelerde önemli konular haline gelmiştir. Mahalli idareleri kuruluş amaçlarına uygun bir şekilde yapılandırmak, güçlendirmek, modern kamu yönetiminin gerektirdiği hesap verilebilirlik, katılımcılık, saydamlık gibi değerleri daha iyi yerine getirebilmelerini sağlamak için özerkliklerini artırıcı düzenlemeler yapılmıştır (Tümer, 2019, s.1).

Mahalli idareler, demokrasinin ayrılmaz ve vazgeçilmez unsurları olmasının yanı sıra, toplumdaki vatandaşlarla da en fazla görüşen, en fazla hizmeti sunan ve bu sebeple belki de en fazla eleştiriye maruz kalan kuruluşlar olmaktadır. Bu kapsamda düşünüldüğünde, finansal açıdan iyi yönetilmeleri, kaynakları verimli kullanmaları, kendine hemşerilik bağıyla bağlı olanlara her türlü altyap1 hizmetini en iyi şekilde sunması gerekmektedir. Bir taraftan kaynaklarının kıt olması diğer taraftan anılan hizmetlerin çok ve çeşitli olması sebebiyle çok daha fazla yeni ve uzun vadeli finansal kaynaklara ihtiyaç duyulmaktadır (Acar, 2019). Bu çalışmada kaynak araştırması, konu ile ilgili ikincil veriler ile örnek olarak incelenen Ankara Su ve Kanalizasyon İdaresi (ASKİ) Genel Müdürlüğü verileri ve özellikle altyapı yatırımlarının finansman kaynaklarının analizi yapılmış ve çalışma sonuçlarına göre mahalli idarelerde büyük ölçekli altyapı yatırımlarının finansmanının geliştirilebilme olanakları ve bu çerçevede sermaye piyasası araçlarının kullanım olanaklarının geliştirilmesi değerlendirilmiştir.

\section{Yöntem}

Çalışmada; literatür taraması, ikincil veriler, örnek olarak incelenen Ankara Su ve Kanalizasyon İdaresi (ASKI)'nin bilanço, performans programı, faaliyet raporu ve bütçe verileri kullanılmıştır. Kaynak araştırması ve nicel veriler kullanılarak yapılan değerlendirme sonuçlarına göre genel değerlendirme yapılmış ve sonuca ulaşılmıştır.

\section{Mahalli İdare Kavramı}

Mahalli idare kavramının birçok şekilde tanımı bulunmaktadır. Maliye biliminin amacı, toplumda yaşanan mali olayları incelemek, sonuçlarını saptamak ve sonuçta onlara yön verebilmektir. Mali olay denilince ilk akla gelen merkezi idare birimleridir. Fakat her ne kadar böyle düşünülse de mali olayların, yalnızca merkezi idare ile sınırlı tutulmaması gerekmektedir. Merkezi idarenin yanı sıra kamu hizmet ve malları sunan, kamu iktisadi teşebbüsleri, mahalli idareler gibi çeşitli birimler de bulunmaktadır (Öncel, 1992, s.6-7). Mahalli idareler, merkezi yönetimin belirlediği sınırlar çerçevesinde, inisiyatifleri doğrultusunda kendisinden hizmet bekleyen toplumun ihtiyaçlarını gidermek için hizmet sunmakta olan birimlerdir (Akbulut vd., 2016, s.352). Mahalli idare, mali ve idari özerkliği olan, katılımcılık ilkesi doğrultusunda aynı 
bölgede ikamet eden halkın ortak ihtiyaçlarını gidermek için kurulan bir yönetim birimidir (Çetinkaya, 2015, s.4).

Devlet, sınırları belirlenmiş bir toprak parçası içinde yaşayan halkın belirli özellikler barındıran ortak ihtiyaçlarını gidermek için kurulan siyasi bir organizasyondur. $\mathrm{Bu}$ siyasi organizasyon kendisini var eden katılımcılarının ortak ihtiyaçlarını karşılamakla sorumludur. Fakat bu ihtiyaçların bazılarının faaliyet alanı bütün ülkeyi kapsarken bir kısım ihtiyaçlar mahalli veya diğer ifade ile mahalli sınırlar içerisinde yaşayan insanlara özgü özelliktedir ve bu ihtiyaçların hepsi merkezi hükümet tarafından karşılanacağı düşünülse bile uzun vadede rasyonel sonuçlar elde edilememektedir. Öyleyse mahalli ihtiyaçlar merkezi idarenin taşra teşkilatlarınca tespit edilmeli ve karşılanmalıdır (Nadaroğlu, 1998, s.3).

Mahalli idareler, yerel özellikteki kamusal ihtiyaçları karşılayan merkezi idarenin tüzel kişiliğinden bağımsız başka tüzel kişiliği olan kurumlardır. Belli bir bölgede yaşayan insanların ortak yaşam alanlarını paylaşması sonucu oluşan ihtiyaçlarını karşılamak ve çıkarlarını korumak için ortaya çıkmışlardır (Türkoğlu, 2009, s.10-12).

Devlet kendi kontrolü dahilinde bazı hizmetleri mevcut olan özerk kuruluşlar gibi kuruluşlara da yaptırabilir (Tortop, 1999, s.10-11). Yerinden yönetim şu şekilde tanımlanabilir, halkın seçmiş olduğu idarelerce yerel kamuya ait olan hizmetlerin yapılması olarak ifade edilen ve âdem-i merkeziyet olarak da bilinen siyasi ve hukuki bir terimdir. Yerel kamusal hizmetleri yerine getiren idarelere ise mahalli idare veya yerel yönetim denilmektedir (Yavuz ve Keleş, 1989). Çağdaş anlamda mahalli idare, devletin tüzel kişilik tanıması ile doğabilmektedir (Karahanoğulları, 2013; Ortaylı, 1982). Batı dünyasında, mahalli idareler merkezi idarenin var olmasından daha önce ortaya çıkmıştır ve bu idarelerin demokrasi bakımından iyi durumda olmalarının yanı sıra kamusal hizmetlerin vatandaşa sunulması ve fonksiyon bakımından vatandaşın yönetim olgusuna katılımının birinci safhası olarak değerlendirilmiştir (Ertan, 2002; (Nadaroğlu, 2001; Toprak, 2010; Uyar, 2004).

\section{Altyapı Yatırımları ve Önemi}

Ekonomide devletlerin en fazla müdahale ettiği kavram olan altyapı; hem fiziki sermayeyi hem de kurumsal, hukuki ve finansal örgütlenmeleri de içeren kapsamlı bir terimdir. Diğer bir tanımda ise; ekonomilerin sahibi olduğu enerji, su ve kanalizasyon, haberleşme, ulaştırma gibi teşekküllerin yanında, sağlık ve eğitim alanında kurumlar ile bu teşekküllerle ilişkili beceri ve bilgiyi de içeren toplumsal sabit sermaye olarak tanımlanabilir (Aktan ve Dileyici, 2005; Aktan ve Dileyici, 2010; Irmak ve Çetin, 2012). Finger vd. (2005) tarafından altyapı kavramı; toplumun ana hizmetlerini tedarik eden, iç içe geçmiş ve karmaşık, iktisadi, politik ve teknik sistemleri içeren bir kavram olarak ifade edilmektedir.

Zorunlu (sert) altyapı (hard infrastructure); maddi bir sabit sermaye oluşumunun sahip olduğu sosyal ve fiziki altyapı olarak tanımlanırken, ihtiyari (yumuşak) altyapı (soft infrastructure) faaliyetleri ise; bu altyapılardan hizmetlerin sunulabilmesinde tamamlayıc1 role sahip olan ve sabit sermaye oluşumunu gerektirmeyen diğer unsurlar şeklinde ifade edilebilir. Kamu altyapı harcamalarının ekonomiye etkisi incelendiğinde temel olarak sosyal ve fiziki altyapı anlaşılmaktadır (Aschauer, 1989; Farhadi, 2015; Munnel, 1990).

Tarihsel olarak düşünüldüğünde altyapıların ana esasını coğrafi özellikler belirlemektedir. Coğrafi niteliklere göre yatırımcıların talepleri ve öncelikleri belirlenerek şekil almakta, yatırımların geri dönüşleri de talepler sonucunda uzamakta veya kısalmaktadır (Kohn ve Pease, 2008). Altyapı kavramı, yatırım yapılmış olan bir yerleşim yerinde aranan; enerji, haberleşme, ulaştırma, su gibi ekonomik imkânların hepsini oluştururken, geniş anlamda ise; başlangıçta sağlık ve eğitimi içermekle beraber beceri ve bilgiyi de kapsayan sosyal sabit sermayeleri de barındırmaktadır. Kısaca altyapı hem ekonomik hem de sosyal yanı olan bir kavramdır (Seval, 2013, s.27). Basit şekilde ekonomik ve sosyal bir birim şeklinde anlaşılsa da Dünya Bankasının 2004 yılındaki raporunda; ekonomi ve endüstri bakımından çok önemli bir 
Tuna ve Bostancı / Mahalli İdarelerde Altyap1 Yatırımlarının Finansman Yöntemleri: Ankara Su ve Kanalizasyon İdaresi (ASKİ) Genel Müdürlügü Örneği / Financial Instruments of Infrastructure Investments in Local Administrations: The Case of Ankara Water and Sewerage Administration (ASKI) General Directorate

görev ve faaliyeti üstlenen üst bir yap1 şeklinde bahsedilmektedir (Snieska \& Zykiene 2009, s.17).

Belirtilen gerekçe ile ekonomi biliminde altyapı kavramı dar anlamda altyapı ve geniş anlamda altyapı olmak üzere iki şekilde anlatılmaktadır. Bunlardan ilki dar anlamda altyapr; yatırımın yapılacağı bölgede yatırımdan beklenen hizmetin verebilmesi için gerekli bütün maddi imkanları ifade etmektedir. Bunlar yatırımın gerçekleşebilmesi için gerekli olan maddi imkanlar, haberleşme, ulaşım, enerji, su ve kanalizasyon hizmetleri gibi hizmetlerden oluşmaktadır. Geniş anlamda altyapı ise daha bütüncül yaklaşımla ekonominin barındırması gereken haberleşme, eğitim ve sağlik, enerji, su ve kanalizasyon gibi konularda hizmetlerin yerine getirilebilmesi için gerekli olan kurum ve tesislerinin varlığını ifade etmektedir. Geniş anlamda altyapı, beceri ve bilgiyi de kapsayan ana sermayenin varlığını içermektedir (Acar, 2019).

Dar anlamda altyap ile anlatılmak istenen hem maddi (ekonomik) ve hem de manevi altyapı hizmetleri iken, geniş anlamda altyapı ise maddi ve manevi altyapı hizmetlerinin yanı sıra eğitim ve sağlık hizmetlerinin bulunduğu sosyal altyapı hizmetlerini barındırmaktadır (Aktan ve Dileyici, 2010). Genel anlamda incelendiğinde Türkiye'de kamunun gerçekleştirdiği altyapı yatırımları, bütçe ve yönetim tarzıyla bağlantılı şekilde iki değişik yönetim birimince gerçekleştirilmektedir. Bunların ilki merkezi hükümet tarafindan yapılan altyapı yatırımları, diğeri ise mahalli idareler tarafından yapılan altyapı yatırımları' dır. Bu çalışmada mahalli idareler tarafindan yapılan altyapı yatırımları incelenmiştir.

Tablo 1.Türkiye'nin 2016-2040 y1lları altyapı yatırım ihtiyacı

\begin{tabular}{lcc}
\hline Sektörler & Altyapı ihtiyacı (Milyar \$) & Pay (\%) \\
\hline Ulaştırma & 581,10 & 59,7 \\
\hline Enerji & 241,50 & 24,7 \\
\hline Telekom & 98,80 & 10,1 \\
\hline İçme suyu & 53,40 & 5,5 \\
\hline Toplam & 974,80 & 100 \\
\hline
\end{tabular}

Kaynak: T.C Başbakanlık Türkiye Yatırım Destek ve Tanıtım Ajansı (ISPAT), (2018)

Türkiye'nin 2016 ile 2040 dönemi altyapı yatırım ihtiyacı incelendiğinde; en yüksek payın \%59,7 ile ulaştırma sektörü yatırımında olduğu anlaşılmaktadır. İkinci sırada 24,7'lik pay ile enerji sektörü gelmektedir (Tablo 1). Özellikle kentlerde toplu taşıma ve raylı sistem yatırımları ile şehirlerarası hızlı tren, otoyol, gar, liman ve havalimanı yatırımlarına büyük ölçüde gereksinim olduğu ve bu tür yatırımların da yüksek maliyetli olması nedeni ile sınırlı bütçe kaynakları ile yapılmasının mümkün olmadığı dikkati çekmektedir (Ünal 2019; Ünal 2021).

\subsection{Mahalli İdarelerce Yerine Getirilen Altyapı Yatırımları}

Mahalli idareler tarafından yapılan altyapı yatırımları mahalli idarelerin tabii oldukları yerel yönetim kanunlarında genel çerçevesi ile açıklanmaktadır. Bunlar yerel yönetimlerin organizasyon yapılarında gösterilen hizmetlerden yararlanılarak şu şekilde özetlenebilir;

Ulaşım Altyapı Yatırımları: Bu hizmetler; 5216 Sayılı Kanun, 5393 Sayılı ve 5302 Sayılı Kanunlarda açılanan ve mahalli idareler tarafından yerine getirmesi zorunlu olan altyapı yatırımları olarak görülmektedir. Bu yatırımlar yerel yönetim sınırları içerisinde yapılan karayolu ile yerine getirilen toplu ulaşım yatırımları, hava ulaşım yatırımları, deniz ulaşım yatırımları, raylı sistem yatırımları ve bunların koordinasyonlarının sağlanmış olduğu terminaller olarak özetlenebilir (Acar, 2019).

Su ve Kanalizasyon Altyapı Yatırımları: Mevzuat olarak İSKİ kanunu olarak bilinen ve İSKİ (İstanbul), ASKİ (Ankara), ASAT (Antalya), İZSU (İzmir) gibi yerel yönetimlerin ve bağlı idareleri olan su ve kanalizasyon idarelerinin de tabii olduğu "2560 sayılı İstanbul Su ve 
Kanalizasyon İdaresi Genel Müdürlüğü Kuruluş ve Görevleri Hakkındaki Kanun” ile belirtilmektedir. Yine diğer yerel yönetim kanunları tarafından yerine getirilmesi zorunlu olan altyapı yatırımlarıdır. Bunlar; temiz su arıtma tesislerinin yapılması, kirli su arıtma tesislerinin yapılması, içme suyu ve endüstriyel temini için gölet ve göllerin yapılması, temiz su temini, temiz ve kirli suların iletim hatlarının yapılması, kirli suların bertaraf edilmesi gibi altyapı hizmetleridir.

Çevre Temizliği, Koruma ve Kontrol Altyapı Yatırımları: Bu hizmetler toplum sağlığının genelini ilgilendiren hizmetlerdir. Çöplerin toplanması ve bertaraf edilmesi, katı atık depolama ve imha tesislerinin yapılması, yerel yönetimlerin sınırları içinde bulunan deniz, akarsu ve derelerin temizliğinin sağlanması için yapılması gereken altyapı yatırımları, hafriyat sahalarının oluşturulması ve toplum sağlığını tehdit eden haşerelerden korunma gibi yatırımlardan oluşmaktadır.

İmar ve Şehircilik Altyapı Yatırımları: Bu yatırımlar yerel yönetimlerin merkezi hükümet ile birlikte müştereken yürüttügü yatırımlardır. Fakat yerel yönetimler kentin yerel dokusunun korunması ve gelişme alanlarının oluşturulmasında ihtiyaçların belirlenmesinde konuya daha hâkim olması sebebiyle daha çok yetkilidir.

Yol Yapımı ve Bakımı Altyapı Yatırımları: Bu yatırımlar her ne kadar merkezi yönetim tarafından yerine getirilen yatırımlar ile benzerlik gösterse de yerel yönetimler kanunların verdiği yetkilere bağlı olarak mahalli idarenin sınırları kapsamında mahalli (yerel) ihtiyaçlar dâhilinde yerine getirdiği altyapı yatırımlarıdır. Bunlar ihtiyaç olması halinde köprülerin inşası, kavşakların yapımı ve tünel yapımı, ilçeleri mahallelerine bağlayan yollar, mahalle içi yollar gibi altyapı yatırımlarıdır. Günümüzde yerel yönetimler kıtaları birbirine bağlayan kanallar, tüneller ve köprülerin yapımını da üstlenmektedir.

Gayrimenkul Yatırımları: Yerel yönetimler kanunların vermiş olduğu yetkilere bağlı olarak sınırları dâhilinde ticarete yön vererek, halkın genel ihtiyaçlarına bağlı olarak birtakım gayrimenkullerin yapımını üstlenebilmektedir. Bunlar; yerel yönetimin yer aldı̆̆ı alanın gelişmesi, yeni iş imkânlarının oluşturulması, il dışından sağlanan bazı hizmetlerin vatandaşlara daha yakın bir hale getirilebilmesi amacıyla yapılmaktadır. Bunlar; rekreasyon alanlarının oluşturulması, ticaret merkezlerinin oluşturulması, mezbaha yapımı, iş merkezlerinin kurulması, toptancı hallerinin yapılması, gelir gruplarına bağlı olarak toplu konutların yapılması, vb. altyapı yatırımlarıdır.

İletişim ve Isınma Altyapı Yatırımları: Bu türdeki altyapı yatırımları Türkiye'de yerel yönetimlerinin yerine getirme zorunluluğu olduğu fakat kaynakların yetersizliği sebebiyle merkezi idare tarafından yapılan ve karşılanan yatırımlarıdır. Fakat bazı yerel yönetimler o yörenin sahip olduğu birtakım yeraltı kaynaklarından faydalanarak 1sınma amacı ile termal suların kullanılması amacıyla birtakım altyapı hizmetlerini yerine getirmektedir. Yine yerel yönetimler için o yörede yeterli iletişim ağı altyapısının oluşturabilmesi veya bu iletişim altyapısının kurulmasının planlanabilmesi önemli hizmetlerdendir.

Sosyal Altyapı Yatırımları: Türkiye'de genellikle yerel yönetimlerin yerine getirmek için ciddi kaynaklar aktardığı altyapı yatırımlarıdır. Halkın bütününü veya ihtiyaç sahibi olan bir kısmını ilgilendirmekte olan bu yatırımlar şu şekilde özetlenebilir; aşevleri yapımı, huzur evleri ve yetimhaneler yapımı, konferans ve sergi salonları yapımı, park ve bahçeler yapımı ile mezarlık alanlarının oluşturulması. Kurumsal finans yatırımcıları için altyapı yatırımları büyük bir potansiyel oluşturmaktadır. Fakat varlıkların yönetimi konusunda tecrübeli olan, bağımsız varlık fonları, sigorta şirketleri, emeklilik fonları gibi kurumsal yatırımcılar açısından gelişmekte olan ülkelerde halen birtakım sorunlar devam etmektedir. Kurumsal sermayeleri, altyapı yatırımlarını çekmek hedefiyle bu pazarlarda başarı garantisi verilmeli, vergi ve bürokrasi gibi engellerde kolaylıklar sunulmalıdır (OECD, 2015). 
Tuna ve Bostancı / Mahalli İdarelerde Altyapı Yatırımlarının Finansman Yöntemleri: Ankara Su ve Kanalizasyon İdaresi (ASKİ) Genel Müdürlügü Örneği / Financial Instruments of Infrastructure Investments in Local Administrations: The Case of Ankara Water and Sewerage Administration (ASKI) General Directorate

\section{Mahalli İdarelerde Altyapı Yatırımlarında Finansman Yöntemleri}

Dünyada diğer ülkelerde olduğu gibi Türkiye'de de merkezi idareler tarafindan yerelleşme faaliyetlerinin sonucunda mahalli idarelere altyapı yatırımlarının yapımı bırakılmaya başlanmıştır. Daha önceki dönemlerde kentlere suyun getirilmesi, enerji, ulaşım için köprü ve geçitler, çevre temizliği gibi hizmetler merkezi idarenin görevleri arasında görülürken, günümüzde ve özellikle yeni Büyükşehir Kanunu ile bütün kırsal kesim ve kentlerin altyapılarının büyük bir kısmı yerel yönetimlerin sorumluluğuna verilmiştir. Günümüzde İstanbul'da, bir mahalli idarenin Marmaray projesi gibi projelerle yerel yönetimlerin altyap1 yatırımlarında aktif olacağının bir göstergesidir (Yaprak, 2020).

Günümüzde mahalli idareler; çevre sağlığı için kirli su arıtma tesisleri kuran ve kirli su atıklarından enerji üreten, katı atık depolama tesisleri kurarak bu tesislerden enerji üreten, çöp tesisleri ile geri dönüşüm tesisleri kuran ve bundan gelir elde eden, içme suyunun kalitesini arttırmak amacıyla barajlar kuran, halkın sağlıklı gıdalar tüketmesi için büyük toptancı hallerini kuran ve işleten, halkın daha sağlıklı koşullarda ikamet etmesi için büyük toplu konut projelerini yürüten, hava ulaşımı terminali kuran ve işleten, ulaşımı daha kolaylaştıran ve rahatlatan terminaller kuran ve işleten, bulunduğu bölgede raylı sistemler kuran ve işleten, marina ve liman projeleri geliştiren ve işleten, hayvan gübrelerini kullanarak enerji üreten ve kırsalın atıklarını değerlendiren, jeotermal enerji ile 1sınma projeleri yapan birimlerdir.

Tablo 2. Mahalli idareler karşılaştırmalı bilanço

\begin{tabular}{|c|c|c|c|c|c|}
\hline & 2012 & 2013 & 2014 & 2015 & 2016 \\
\hline 3.Kısa vadeli yabancı kaynaklar & 26.833 .412 & 30.570 .499 & 27.618.351 & 31.860 .831 & 35.397 .675 \\
\hline K1sa vadeli iç mali borçlar & 8.114 .223 & 5.446 .348 & 3.539 .148 & 4.303 .993 & 5.413 .065 \\
\hline 300 Banka kredileri & 2.010 .154 & 2.601 .639 & 2.536 .705 & 3.066 .027 & 3.871 .564 \\
\hline Kısa vadeli diğer iç mali borçlar & 96.494 & 24.365 & 19.067 & 15.746 & 12.349 \\
\hline 4.Uzun vadeli yabancı kaynaklar & 22.099 .252 & 24.673 .755 & 28.345 .081 & 31.717 .236 & 45.265 .705 \\
\hline 403 Kamu idarelerine mali borçlar hesabı & 7.580 .440 & 4.814 .022 & 6.970 .813 & 7.559 .310 & 8.696 .573 \\
\hline Uzun vadeli diğer iç mali borçlar & 528.750 & 50.050 & 26.888 & 24.215 & 26.721 \\
\hline 41 Uzun vadeli dış mali borçlar & 5.659 .646 & 5.961 .022 & 5.496 .437 & 6.016 .749 & 8.041 .839 \\
\hline 410 Diş mali borçlar & 5.659 .646 & 5.961 .022 & 5.496 .437 & 6.016 .749 & 8.041 .839 \\
\hline
\end{tabular}

Kaynak: Hazine ve Maliye Bakanlığı Muhasebat Genel Müdürlüğü (2021)

Mahalli idarelerin 2012 ile 2016 yılları arası bilançoları incelendiğinde; uzun vadeli yabancı kaynaklar ile kısa vadeli yabancı kaynaklar ve her geçen yıl artış gösterdiği görülmektedir. Uzun vadeli yabancı kaynaklarda, kısa vadeli yabancı kaynaklara kıyasla tutarların daha fazla olması mahalli idarelerin genellikle uzun vadeli borçlanmayı tercih ettiklerini göstermektedir. Ayrıca kısa vadeli yabancı kaynaklar sadece yurt içinden banka kredileri iken uzun vadeli yabancı kaynaklarda hem banka kredileri hem de dış mali borçlar da bulunmaktadır. Mahalli idareler dış mali borçlanma yoluna da başvurmaktadır (Tablo 2).

Tablo 3. 2020 yllı merkezi yönetimin mahalli idarelere cari transferleri

\begin{tabular}{|c|c|c|c|c|}
\hline $\begin{array}{c}\text { Cari Transferler (Milyon } \\
\text { TL) }\end{array}$ & İl Özel İdareleri & Büyükşsehir Belediyeleri & Büyükşehir İlçe Belediyeleri & Diğer Belediyeler \\
\hline Şubat & 339 & 3.539 & 3.034 & 1.011 \\
\hline Nisan & 185 & 1.768 & 1.663 & 554 \\
\hline May1s & 246 & 2.520 & 2.211 & 737 \\
\hline Haziran & 280 & 2.874 & 2.487 & 829 \\
\hline Ağustos & 380 & 3.920 & 3.421 & 1.140 \\
\hline Eylül & 494 & 5.160 & 4.430 & 1.477 \\
\hline Ekim & 345 & 3.477 & 3.074 & 1.025 \\
\hline Kasım & 383 & 3.961 & 3.448 & 1.149 \\
\hline Aralık & 509 & 5.431 & 4.581 & 1.527 \\
\hline Toplam & 4.137 & 42.399 & 36.770 & 12.257 \\
\hline
\end{tabular}

Kaynak: Hazine ve Maliye Bakanlığı Muhasebat Genel Müdürlüğü (2021) 
Maliye ve Hazine Bakanlığı Muhasebat Genel Müdürlüğü verilerine göre; 2020 y1l1 merkezi yönetimin mahalli idarelere payları ocak ve aralık ayları toplamı il özel idarelerine 4.137.000 TL, büyükşsehir belediyelerine 42.399.000 TL, büyükşehir ilçe belediyelerine 36.770.000 TL, diğer belediyelere 12.257.000 TL'dir. En büyük payı büyükşehir belediyeleri almaktadır (Tablo 3, Şekil 1).

Yukardaki rakamlara Büyükşehir belediyelerinin bağlı kuruluşları olan su kanalizasyon idareleri ve ulaşım idareleri dahil değildir.

Şekil 1. Mahalli idare payları

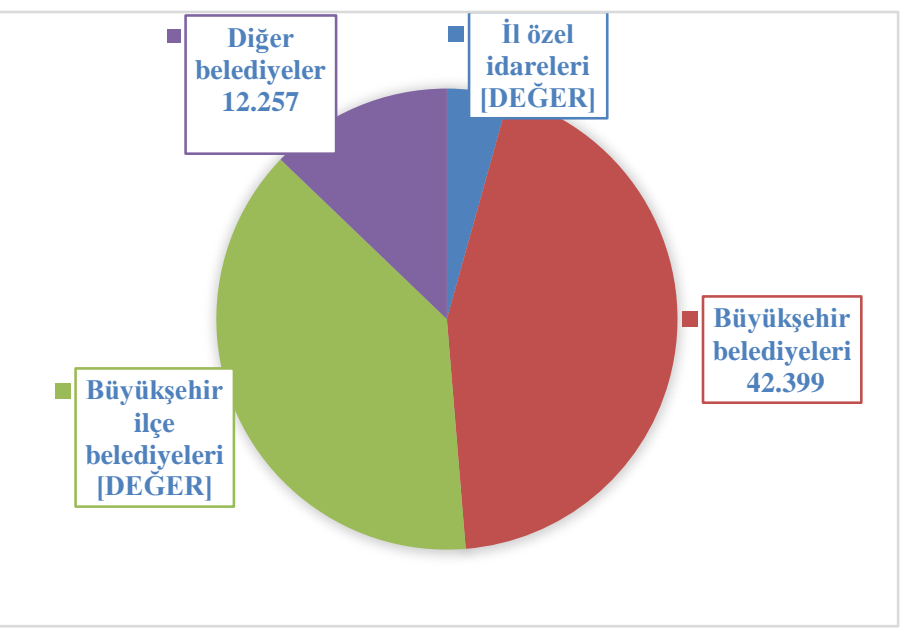

Kaynak: Hazine ve Maliye Bakanlığı Muhasebat Genel Müdürlüğü (2020)

Maliye ve Hazine Bakanlığ1 Muhasebat Genel Müdürlüğ̈̈ verilerine göre; 2020 y1l merkezi yönetim bütçe giderleri gerçekleşmesi ocak ve aralık ayları toplamı 1.202.236.000 TL'dir. En yüksek olduğu ay aralık ayıdır.

Maliye ve Hazine Bakanlığı Muhasebat Genel Müdürlüğü verilerine göre; 2020 yılı merkezi yönetim bütçe giderleri gerçekleşmesi ocak ve aralık ayları toplamında mahalli idarelerin payları yüzdesel olarak incelendiğinde; Büyükşehir belediyeleri en yüksek paya sahiptir ve merkezi yönetimin tüm giderler içerisinde büyükşehirlere verilen pay $\% 3$ civarında bu oran tüm giderler içinde çok düşük kalmaktadır (Tablo 4).

Tablo 4. 2020 yılı merkezi yönetim bütçe giderleri gerçekleşmesi

\begin{tabular}{ccccc}
\hline & İ Özel İdareleri & Büyükşehir Belediyeleri & Büyükşehir İlçe Belediyeleri & Diğer Belediyeler \\
\hline Ocak & 3,33 & 0,33 & 0,37 & 1,12 \\
\hline Şubat & 2,76 & 0,26 & 0,31 & 0,92 \\
\hline Mart & 2,54 & 0,24 & 0,28 & 0,85 \\
\hline Nisan & 5,86 & 0,61 & 0,65 & 1,96 \\
\hline Mayıs & 3,47 & 0,34 & 0,39 & 1,16 \\
\hline Haziran & 3,06 & 0,30 & 0,34 & 1,03 \\
\hline Temmuz & 3,69 & 0,41 & 0,47 & 1,40 \\
\hline Ağustos & 2,11 & 0,20 & 0,23 & 0,70 \\
\hline Eylül & 2,20 & 0,21 & 0,25 & 0,74 \\
\hline Ekim & 2,83 & 0,28 & 0,32 & 0,95 \\
\hline Kasım & 2,51 & 0,24 & 0,28 & 0,84 \\
\hline Aralı & 2,72 & 0,25 & 0,30 & 0,91 \\
\hline Toplam & 2,91 & 0,28 & 0,33 & 0,98 \\
\hline
\end{tabular}

Kaynak: Hazine ve Maliye Bakanlığı Muhasebat Genel Müdürlüğü (2020)

Türkiye'de merkezi idare son 10 yılda yeni altyapı yatırımlarının finansmanı için alternatif ve yeni finansman tekniklerini geliştirmekte ve uygulamaya başlamaktadır. Yasal olarak yapılması gereken yeni düzenlemelerle yerel yönetimlerde hali hazırdaki ve yeni yatırımların finansmanında, merkezi idarenin uygulayacağı yeni finansman tekniklerini 
Tuna ve Bostancı / Mahalli İdarelerde Altyapı Yatırımlarının Finansman Yöntemleri: Ankara Su ve Kanalizasyon İdaresi (ASKİ) Genel Müdürlügü Örneği / Financial Instruments of Infrastructure Investments in Local Administrations: The Case of Ankara Water and Sewerage Administration (ASKI) General Directorate

uygulanabilir hale getirecektir. Yerel yönetimlerin uygulamalarında bazı farklıl1klar olsa da merkezi idare ile benzer finansman tekniklerini kullanmaktadır. Bunlar, finansman şirketleri ile yapılan özel uygulamalar ve özel sektör şirketleriyle yapılan sözleşmelere dayanan özel imtiyazlar, sermaye piyasası araçları ile finansman şeklinde özetlenebilir. Dünyadaki ülke örneklerinde olduğu gibi Türkiye'de de son yıllarda altyap1 yatırımlarında, bazı yasal düzenlemeler yapılarak aşağıda belirtilen alternatif finansman yöntemleri uygulanmaktadır.

\section{1. İller Bankası Finansmanı}

"İller Bankası A.Ş. ("Banka") 11 Haziran 1933 tarih ve 2301 sayılı Kanunla "Belediyeler Bankası" şeklinde oluşturularak kurulmuştur. 13 Haziran 1945 tarih ve 4759 sayılı "İller Bankası Kanunu" ile bankanın sorumluluk, yetki, görevleri ile birlikte bankanın ismi değiştirilmiş İller Bankasına dönüşmüştür. 8 Şubat 2011 tarih ve 27840 say1lı Resmi Gazetede yayımlanarak yürürlüğe girmiş olan 6107 sayılı "İller Bankası Anonim Şirketi Hakkında Kanun" (Banka Kanunu) ile Banka'nın devamı niteliğinde sorumluluk, yetki ve görevleri aynı şekilde kalarak, Illler Bankası Anonim Şirketi şekline dönüşmüştür"

İler Bankası, nominal sermayesi 30.000.000 TL olan ve ortaklarının tamamı belediye ve il özel idarelerinden oluşan, görevleri arasında kentsel projelerin altyapı ve üst yapı yapımına yardımcı olmak, danışmanlık yapmak olan bir yatırım ve kalkınma bankasıdır. 6107 sayılı İller Bankası A.Ş. kanunda da belirtildiği gibi asli fonksiyonu; mahalli idareler ve bağlı kuruluşları, il özel idareleri, mahalli idare birliklerinin finansman ihtiyaçlarını karşılamaktır (İlbank, 2020).

2019 yılı itibarı ile krediler toplamı 27.394.959.000 TL 2020 eylül ayı itibari ile 29.689.563 TL olan, güçlü sermaye yapısı (2020 yılı eylül ayı ödenmiş sermayesi: 18.707.261 TL) ile İller Bankası yerel yönetimlere; uzun vadeli, orta vadeli, kısa vadeli krediler ile teminat mektupları gibi özelliklerine göre birçok farklı kredi türü temin etmektedir. Yatırım bankası olması sebebiyle İller Bankası 2007 yılından beri özel durumların haricinde kısa vadeli ihtisas kredisi kullandırmaktadır. İller Bankası kaynaklarından finansman sağlayacak mahalli idareler, krediyi temin etmeden önce ayrıntılı inceleme için bazı prosedürleri yerine getirme zorunluluğu vardır. Kısa vadeli nakit kredilerde ve yatırım kredisinde mahalli idareler, kullanacakları kredinin geri ödenmesinin temini için bir ödeme planı ve bütçelerinde kredi finansmanının karşılanacağı gelir kalemini bildirme zorunluluğu bulunmaktadır (Ökmen ve Koç, 2015, s.556).

Genel olarak finansman ve gelir yetersizlikleri sebebiyle yabancı kaynak kullanmak zorunda olan yerel yönetimlerin finansman kaynakları arasında İlbank A.Ş. ana finans kaynağı şeklinde ifade edilmektedir. Yerel yönetimlerin mevcuttaki teşkilatlanmaları, günümüzde kaynak kullanımındaki eğilimleri ve becerileri sebebiyle farklı finansal kaynaklara ulaşmalarını kısitlamaktadir.

\subsection{Yurtiçi Bankalardan Borçlanma Yoluyla Finansman}

Merkezi idareden alınan payların az olması ve vergi gelirlerinin yeterli olmaması nedeniyle, yerel yönetimler birtakım yatırımlarını yurtiçi konvansiyonel banka kaynakları ile gerçekleştirmektedir. Yerel yönetimler bakımından yurtiçi bankalardan borçlanmayı seçmeleri, İller Bankasına kıyasla, ekonomik göstergelerin daha iyi olduğu zamanlarda faiz oranları nispetten daha makul seviyede ve maliyetleri daha düşük olduğundan tercih edilmekte ve finansman sağlanmaktadır.

Türkiye'de ticari bankalar, mahalli idareleri sonuçta kamu kurumu niteliğinde bir kuruluş şeklinde benimsemeleri ve bütçe gelirlerinin arka planında merkezi hükümetin bulunmasından sebeple kredileri fiyatlandırırken ticari kredi faizlerinin altında makul cazip fiyatlandırmaya sevk etmektedir. Mahalli idareler bakımından borçlanma işlemleri, uymak zorunda oldukları bazı kurallar ve prosedürler bütünüdür. Borçlanmaya sebep olan temel neden; hazırlanan bütçelerde yetecek kadar gelir kaleminin olmamasıdır. Mahalli idareler bütçe giderlerini karşılayabilmek, borçlarda ödeme ile ilgili sıkıntı yaşamamak ve vermiş oldukları taahhütleri yapabilmek için zorunlu olarak borçlanmaktadırlar. Her yıl Ekim-Kasım aylarında 
(ilçe belediyelerinde Ekim ayında, Büyükşehir Belediyelerinde Kasım ayı) gelecek bir sonraki yıla ait hazırlanan bütçelerinde gelirlerinin, giderlerini karşılayamaması halinde yerel yönetim yöneticisi bu duruma dair çözüm önerileri geliştirmektedir.

Mahalli idarelerde iç borçlanma, söz konusu yerel yönetim meclisinin yetkisinde bulunmaktadır. Ancak iç borçlanma yoluyla kaynak temini bütçenin \%10’u ile sınırlı olup, $\% 10$ 'dan daha fazla yapılacak iç borçlanma talepleri, belediye ve il özel idaresinin meclisinin salt çoğunluğu ve İçişleri Bakanının onayına tabidir. Ayrıca iç ve dış borç stoku belediyeler ve il özel idareleri için, en son kesin olan bütçe gelirleri toplamının 213 sayılı Vergi Usul Kanunu'nda belirtilen yeniden değerleme oranıyla değerlenme yapıldıktan sonraki tutarını geçemez. Bu oran büyükşehir belediyelerinde 1,5 kat şeklinde hesaplanır.

\subsection{Yurtdışı Bankalar Yoluyla Finansman}

Kamu idareleri harcama yapabilmeleri için bütçelerinde ödenekleri olmalıdır. Bütçe hazırlanırken altyapı yatırımlarının hangi biçimde ve şekilde finanse edileceğine karar veren yerel yönetim yöneticileri, yatırımlara daha ucuz finansman bulabileceği kanısıyla bir diğer finansman yöntemi olarak, yurtdışı borçlanmayı finans kaynağı şeklinde düşünmektedir. Aslında yerel yönetim bakımından tercih edilen yöntem döviz riski taşıyor olsa da, yurtdışı kaynaklarının daha uzun vade ve uygun faiz oranları içermesi, Türkiye'nin yerel kaynaklarının yeterli olmaması, yurtdışı finans sağlayan kuruluşların ülkenin altyapı yatırımlarına yatırım yapma isteğinin bulunması, yerel yönetimlerin bu yöntemi seçmelerinin sebebi olarak görülebilir.

Mahalli idareler görev ve yetkilerinde bulunan hizmetleri gereği gibi yapabilmek için borçlanma yoluna gitmek zorundadır (5393 Sayılı Bel.Kan.m.66). Bütçe gelir gider dengesini oluşturamayan, altyapı yatırımlarını yapabilmek için bütçe gelirleri ile kaynak sağlayamayan yerel yönetimler için bu bir kanuni zorunluluk olmaktadır. Türkiye'de mahalli idarelerin yurtdışı finansman kaynaklarına başvurabilmeleri için bazı yasal düzenlemeler bulunmaktadır. $\mathrm{Bu}$ düzenlemeler merkezi idarenin yerel yönetimler üzerindeki vesayet yetkisi sebebiyle birtakım kısıtlamalarla daraltılmaktadır ve sıkı kontrol altına alınmaktadır. İnsan kaynaklarının yeterli olmaması, kur riskinden dolayı oluşacak sorunlar ve finansal kaynağın kullanılması esnasında verilecek yanlış kararlar, yerel yönetimlerin ve ülke hazinesinin zor durumda kalabileceği kanısı; bu kısıtlamaların ve koşulların oluşmasında büyük etki göstermektedir. Özellikle Türkiye'de yerel yönetimlerin finansal yönetim ile ilgili insan kaynakları bakımından uzmanlaşamaması ve Türkiye'nin finansal piyasalarının tam anlamında gelişmemesi merkezi idarenin bu gibi borçlarda ülke çıkarları ve menfaati ile uyuşmayacak sözleşmelerin oluşabileceği düşüncesi ve güvensizliği sebebiyle yurtdışı kaynaklara ulaşmakta bazı kısıtlamalar uygulanmasını zorunlu hale getirmiştir (Ökmen ve Koç, 2015, s.556).

"5393 sayılı Belediye Kanunun 68/f maddesinde, 703 say1lı Kanun Hükmünde Kararname ile yapılan değişiklik ile yurtdışı borçlanmaya ilişkin getirilen diğer bir kısıtlama ise, ileri teknoloji gerektiren büyük tutarlardaki altyapı yatırımlarının borçlanılmasında sadece Cumhurbaşkanın onayladığı projelerde dış borçlanma yapılmasında kısıtlama bulunmamaktadır". Yerel yönetimlerin yurtdışı borçlanmayı tercih etmeleri halinde, iki tür yurtdışı borçlanma yöntemi bulunmaktadır. Bunlarda ilki; bir kamu idaresi olması sebebiyle, hazine garantisini güvenerek yurtdışı fon kaynaklarına başvurmadır. İkincisi ise, hazine garantisi olmadan borçlanmadır.

\subsubsection{Hazine Garantili Borçlanma}

Yurtdışı finansman kaynaklarını kullanacak yerel yönetimler, hazine garantisi ile daha uygun fiyat alabilme veya kullanılacak fonda ilgili garantinin zorunlu olması, yurtdışı finansman kaynaklarının teminatlanması bakımından, hazine garantisi ile borçlanma tercih edilebilmektedir. $\mathrm{Bu}$ garanti kısmen de olabildiği gibi, yükümlülüğün tamamını da içerebilmektedir. Yerel yönetimler hazine haricinde başka bir kuruluşun vereceği garanti ile de 
Tuna ve Bostancı / Mahalli İdarelerde Altyapı Yatırımlarının Finansman Yöntemleri: Ankara Su ve Kanalizasyon İdaresi (ASKİ) Genel Müdürlüğü Örneği / Financial Instruments of Infrastructure Investments in Local Administrations: The Case of Ankara Water and Sewerage Administration (ASKI) General Directorate

dış finansman sağlayabilmektedir. Hazine ve Maliye Bakanlığı tarafindan garanti veren kuruluşa verilen "karşı garanti" adı altında bir garanti ilgili dış kaynağın teminini sağlanmaktadır (4749 sayılı Kanun M.3).

Yine "4749 sayıl1 Kanunun beşinci bölümünde belirtilen; Hazine Garantileri ve Borç Üstlenimi faslında belirtildiği üzere, verilecek tüm garantiler üzerine yapılan müzakereler, temaslar ve hazırlıklar konusunda yapılan tüm çalışmaları kamu adına Hazine ve Maliye Bakanlığı yürütmektedir. Kamu Finansmanı Genel Müdürlüğü, dış finansmanın gerçekleştirirken dört farklı yöntem uygulamaktadır (4749 Sayılı Kanun Kapsamında Dış Finansman Sağlanmasına İlişkin Usul ve Esasları Yönetmeliği)." Bunlar şöyle sıralanmaktadır: dış borcun tahsisi, dış borcun ikrazı, dış borcun devri ve sonuncusu ise, Hazine tarafından yurtdışına ihraç edilen borçlanma senetleri ile elde edilen kaynă̆ın tahsis edilmesidir.

Mahalli idarelerle bunlara ait tüzel kuruluşlar ve sermayesinin \%50'sinden fazlasını elinde bulundurduğu tüzel kişiliklerin, hazine garantisiyle elde ettikleri diş finansman kaynaklarının ödenmemesi ya da aksatılması durumunda Hazine ve Maliye Bakanlığı borç ve yükümlülüklerden müteselsil sorumludur.

\subsubsection{Yurtdışından Doğrudan Borçlanma}

Mahalli idareler hazinenin garantisi olmadan da dış borçlanma için yurtdışı fon kaynaklarına başvurabilmektedir. Buna doğrudan yurt dışı borçlanması denilmektedir. Fakat uygulamada bu durum mahalli idarelerin borçlanması olduğundan fiiliyatta doğrudan borçlanılsa da, yasal olarak mahalli idarelerin merkezi idarenin izni olmaksızın bu şekilde borçlanmaı olanağı bulunmamaktadır. Doğrudan borçlanmadan kasıt hazinenin garantisi olmadan borçlanmadır. Hazine bu borçlanmada mahalli idarenin üstleneceği yükümlülüklere, müteselsilen kefil olmamaktadır. Fakat yurtdışı borçlanmaya izin verip, vermeme yine Hazine ve Maliye Bakanlığı'nın onayına tabidir.

“4749 sayılı Kamu Finansmanı ve Borç Yönetiminin Düzenlenmesi Hakkındaki Kanun Kapsamında Dış Finansman Sağlanmasına İlişkin Usul ve Esaslar Hakkında çıkarılan yönetmeliğin 5. maddesinde belirttiği üzere borçlanmayı gerçekleştirecek kurum her halükârda ilk olarak Kamu Finansmanı Genel Müdürlüğü'ne müracaat edecektir. Müdürlükçe finansman çalışmalarına başlanmadan önce projenin yatırım programındaki yeri, ihtiyacı, önceliği, yıllara sair olarak ilgili projeye aktarılacak ödenekleri öğrenmek için Cumhurbaşkanlığı Strateji ve Bütçe Başkanlığı'ndan uygun görüş sorulmaktadır. Uygun görüş verilmesinden sonra Kamu Finansmanı Genel Müdürlüğü uygun görüşü ve Hazine ve Maliye Bakanı'nın onayı alınarak yerel yönetimin yurtdışı finansmanı kullanmasına izin verilmektedir. Fakat mahalli idarelerin devleti herhangi bir borç işlemine uğratmaması amacıyla dış finansmanın tahsisinin doğrudan Hazine ve Maliye Bakanlığı'nca yapılması esas olmakla beraber, bazı hallerde finansmanın doğrudan ilgili idarece yüklenilmesine izin verilmektedir”. (Kamu Kurum ve Kuruluşlarının Hazine Garantisi Olmaksızın Hibe Hariç Dış İmkân Sağlanmasına İzin Verilmesine ve Sağlanan Dış İmkânın İzlenmesine İlişkin Yönetmelik, 2009, M.5/3).

\subsection{Kamu Özel İşbirlikleri (Public Private Partnership)}

Kamu kuruluşlarının, inşası devam eden yatırımları ve planladığı yatırımları gerçekleştirebilmesi için çok büyük kaynaklara ve bu kaynakların etkin ve verimli kullanılmasına gereksinim duyulmaktadır. Bu tip projelerin mevcut öz kaynaklarla gerçekleştirilmesi gayet zor ve bu yetersiz bütçe gelirleri ile gerçekleştirilmesi ciddi zaman kayıplarına sebep olmaktadır.

Kaynakların yetersiz olması kamuyu projelerin finansmanında yeni metotlar bulmaya ve oluşan liberal politik stratejiler karşısında yeni politikalar üretmeye yönlendirmektedir. Kamu hizmet tesislerinin doğrudan inşası, tesislerin finansmanı için bütçelerinden kaynak aktarılması, hizmetin ifası için kendi personelinin çalıştırılmasının yerine; bu tesislerin inşası, finansmanı, işletilmesi hususlarına özel sektörü dâhil ederek, yalnızca kontrol ve denetimin kamunun eliyle 
yürütüldüğü kollektif bir çalışmaya yöneltmektedir (T.C. Cumhurbaşkanlığı Strateji ve Bütçe Başkanlığı, 2020).

Ülkeler bazında altyapı yatırımlarının özel sektör katılımı ile yapılmasında büyük düşüşlerin yaşandığ 1 son 5 yılda Türkiye enerji ve ulaşım sektöründe yaptığ1 yatırımlarla son 5 yılın en fazla altyapı yatırımını yapan ilk 5 ülke arasına girmiştir. Kamu-Özel-İşbirliği modelleri ilk etapta altyapı tesislerinin yatırımlarının finansmanı olarak düzenlenmiş sözleşmeler şeklinde anlaşılsa da, aslında özel sektörün işletmecilik becerilerinden yararlanılan ve kamunun asli görevleri olan denetim, planlama ve politika belirleme yönlerine daha çok ağırlık vermesini sağlayan yönetim metodudur (Özkaya, 2016).

1999 yılında Anayasanın 46. maddesinde yapılan değişiklikle devlet tarafından yürütülen birtakım kamu hizmetlerinin özel teşebbüs tarafından, kanun oluşturmak şartıyla özel hukuk hükümleri kapsamında düzenlenecek sözleşmeler yoluyla yaptırılabileceği hususu eklenmiştir. Kamunun yatırım hedeflerinin oluşturulmasında yol gösterici olan 11. Kalkınma Planında Kamu Özel İşbirliği (KÖİ) modelleri ve yatırım alanları hakkında ayrıntılı yer verilmiştir. Türkiye'de yerel yönetimlerin, altyapı yatırımlarının artması ve hizmetlerine karşılık gelirlerinin yeterli olmaması, yerel yönetimleri birtakım hizmetleri özel sektör ile beraber ortak yürütülmesi yoluna yöneltmiştir. Bunun sonucunda üretilen hizmetin karşılığında özel sektör yatırımcısına; hizmetinin karşıllğında ücret veya gelir getirici hizmet gelirinin paylaşılması yöntemi taahhüt edilmiştir.

Türkiye'de uygulanan KÖİ modelleri; Yap-Kirala-Devret, Yap-İşlet, Yap-İşlet-Devret ve İşletme hakkının devridir. 2020 verilerine göre; Türkiye'de gerçekleştirilen KÖİ projelerinde 4 farklı KÖİ modeli kullanılmaktadır. En çok kullanılan model 120 projeyle yap-işlet-devret, 109 projeyle işletme hakkı devri, 18 projeyle yap-kirala-devret ve 5 projeyle yap-işlet modeli olarak sıralanabilir. Sektör düzeyinde KÖİ projelerinin dağılımında ilk sırayı 23,3 milyar ABD \$ ile karayolu sektörü almakta ve bunu 18,7 milyar ABD \$ ile enerji sektörü izlemektedir. Yapkirala-devret ile yapılan sağlık projeleri 10,8 milyar ABD \$ ile 4.sırada yer almaktadır. İşletme hakkı devri bedellerinin sektörel dağılımında havaalanları 54,2 milyar ABD \$ ile ilk sıradadır (T.C. Cumhurbaşkanlığı Strateji ve Bütçe Başkanlığı, 2020).

Özellikle yatırımlarını finanse eden özel sektör, borçlanma maliyetleri bakımından devletten daha yüksek oranlarla borçlanmaktadır. Bu sebeple yatırımların özel sektörce yaptırılması faiz maliyetleri bakımından yükseltici etki oluşturmaktadır. Yine yatırımların finansmanında hazine garantilerinin bulunduğu sözleşmelerde tek taraflı olarak fesih edilmesinde borç yükleniminin uygulanması ve KÖİ sözleşmeleri riskinin hepsinin kamu tarafından üstlenilmesi, kamu bakımından ileriki dönemlerde çok fazla miktarda risk alınmasına sebep olmaktadır. Bir diğer eleştiride, yapılan yatırımın atıl bir durumda kalması ve bu yatırımın ayakta kalabilmesi için çok fazla miktarda sabit giderlerin ödenmesidir. Bu çeşit yatırımlar, kamu kaynaklarının israfıdır ve bu yatırımdan vazgeçilmesi halinde yüksek miktarda kaynağın heba olması sebebiyle vazgeçilemeyen kamunun üzerinde yük olan yatırımlardır (Bozlağan, 2003, s.323-324).

\section{5. İştirakler Yoluyla Finansman}

Türkiye'de iştirak kavramı ilk olarak kamu iktisadi teşekküllerin kurulması ve faaliyetleri ile gündeme gelmiştir. Yerel yönetimler bakımından ise, Belediye iktisadi teşekkülleri ve özellikle Büyükşsehir Belediyesi İktisadi Teşekkülleri öne çıkmaktadır. Yerel yönetimlerin iktisadi teşekkül kurmasındaki amaç; doğal yerel tekel konumundaki ulaşım, su ve doğalgaz gibi varlıkları işletmek ilk sıralardadır. İkinci sırada sosyal belediyecilik gereğince birtakım temel maddelere ulaşımı sağlamak amacıyla kurulan; mezbaha, ekmek, tanzim satış mağazaları vb. işletmeler bulunmaktadır. Bir diğeri ise yerel yönetimlere ek gelir sağlamak için oluşturulan işletmelerdir. Bunlar yerel bölgenin kalkınmasını sağlamak, yerel yönetime ek gelir sağlamak amacıyla kurulan iktisadi teşekküllerdir. Bunların iş alanları ise yerel ürünlerin 
Tuna ve Bostancı / Mahalli İdarelerde Altyapı Yatırımlarının Finansman Yöntemleri: Ankara Su ve Kanalizasyon İdaresi (ASKİ) Genel Müdürlügü Örneği / Financial Instruments of Infrastructure Investments in Local Administrations: The Case of Ankara Water and Sewerage Administration (ASKI) General Directorate

üretildiği ve pazarlandığı tesisler, iş hanları, kaplıca tesisleri, toplu konut idareleri, otoparklar, kum ve micır ocakları, oteller, su ve maden suyu tesisleri şeklindedir.

Yerel yönetimler bakımından önemli bir finansman yolu olan iştiraklerle finansman sağlama Türkiye'de farklı şekillerde uygulama alanına sahiptir. Bunlar; mevcut bir özel hukuk tüzel kişisine ortak olmak, şirket kurmak ve hibe ile şirket devralmaktır. Yerel yönetimler hizmet ve görev alanları dişında bir şirket kuramaz ve ortak olamazlar. Bu ortaklıkların kurulmaları merkezi idarenin sıkı vesayet denetiminde olduğundan Cumhurbaşkanlığı onayı alınması yasal bir zorunluluktur (Mahalli İdareler Genel Müdürlüğü 2008/31 Sayılı Genelge).

\section{6. Özelleștirme Yoluyla Finansman}

1970’li y1llarda tartış1maya başlanan özelleştirme kavramı, özellikle 1980'li yıllarda ülkelerin gündeminde çokça yer almıştır. Türkiye'nin gündemine de 1980'li yıllarda girmiştir (Vural, 2015, s.19). Belediyeler limited şirketlerdeki paylarını, anonim şirket niteliğindeki iştirak paylarını ve bu payları gösteren hisse senetlerini, üçüncü kişilere belediye meclisi kararıyla satabilir ve devredebilir. 4046 sayılı Özelleştirme Kanunu'nun 26. maddesi de "belediyelere ait ticari amaçla kurulmuş işletmeler ile pay nispetleri dikkate alınmaksızın her çeşit iştiraklerde bulunan paylarının özelleştirilmesiyle ilgili işlemlerin yetkili birimiyle (belediye meclisi) saptanıp yürütülebileceği belirtilmiştir" (Bozlağan, 2003). Türkiye'de yapılan özelleştirmeler genellikle merkezi yönetimin bütçe açıklarının finansmanında kullanılmaktayken, yerel yönetimlerde özelleştirme; barınaklar, ilaçlama ve halk sağlığ hizmetleri, temizlik hizmetleri, toplu konut yapımı, çöp toplama ve ulaşım vb. hizmetlerin özel sektör tarafından yaptırılmasıyla idari ve mali tasarruf sağlanacağı düşünülmektedir.

\subsection{Tahvil Yoluyla Finansman}

Tahvil; vadesi bir yıldan daha uzun borçlanma araçları şeklinde tanımlanmaktadır. Özellikle 1990'lı yıllarda Türkiye'de İstanbul ve Ankara Büyükşehir Belediyelerinin tahvil ihraç denemesi olmuştur. İhraç edildiği ylllarda ülke ekonomisinin içiresinde bulunduğu belirsizlikler sebebiyle yeterli talebin sağlanamaması ve Türkiye'de sermaye piyasası araçlarının yeterince gelişememesi sebebiyle, ihraç eden belediyelerin yeterli verimi alamaması ile sonuçlanmıştır (Dinçsoy, 2001, s.45).

Tahvil; geri ödeme periyotlarındaki esneklikler, vade uzunluğu vb. özellikleriyle altyap1 yatırımlarının finansmanı bakımından, alternatif bir finansman aracı olarak görülmektedir. Avrupa ve Amerika Birleşik Devletleri (ABD)'nde yerel yönetimlerce sıklıkla kullanılan, finansman yöntemidir. Ayrıca ABD'de yerel yönetim tahvillerinin bulunduğu, alım- satımın yapıldığ yönetimlerce ihraç edilen tahvillerin; bankacılık sektörüne alternatif olmakla katkı sağlamakta ve sermaye piyasalarının gelişmesine de yardımcı olmaktadır. Sağlanan vergi avantajları ve temerrüt oranlarının düşüklüğüyle de yatırımcı için alternatif güvenilir yatırım aracı olarak görülmektedir. Ayrıca yerel yönetimlerin şeffaflı̆̆ ve denetlenmesi bakımından da gelişmesini, mali disipline uygun davranmasını zorlayan bir finansman yöntemidir (Özer, 2016, s.49). Yerel yönetimler bakımından yasal mevzuatı bulunan tahvillerin hem yurtiçi hem de yurtdış1 finansman sağlama firsatı da bulunmaktadır. Türkiye'de son 15 yılda oluşturulan siyasi güven ve istikrar ortamında, sağlanacak vergi avantajları ve hazine veya İlbank tarafından verilebilecek garanti ile yerel yönetimlere altyapı yatırımlarının gerçekleştirilmesinde uzun vadeli, ciddi kaynak oluşturma potansiyeli bulunmaktadır.

\subsection{Mahalli İdarelerin Altyapı Yatırımlarının Finansmanında Alternatif Bir Yöntem Olarak Sukuk İhracı}

Mahalli idarelerin altyapı yatırımlarının finansmanında alternatif yöntem olarak sukuk ihracı, diğer yöntemlere göre daha yeni bir kavramdır ve bu nedenle çok bilinmeyen ve çok kullanılmayan bir yöntem olarak da kabul edilebilir. 
Altyapı yatırımları kamuya ait bir gayrimenkulle ilgili olması nedeniyle birçok bakanlığın yetki ve sorumluluk alanını ilgilendirmektedir. Önerilen model Türk hukuk sisteminde bir borçlanma aracı şeklinde görülmesinden dolayı Cumhurbaşkanlığı ile bakanlıkların ve bazı düzenleyici ve denetleyici kurumların denetim ve yetki alanı içine girmektedir. Bu nedenle mahalli idarelerin sukuk ihracıyla ilişkili kuruluş ve kurumlarla sık1 bağlantı ve koordinasyon sağlanması gerekmektedir. Fakat mevcut hukuki durumda mahalli idarelerin doğrudan sukuk ihracı olanağı mevcut değildir. Hukuki eksikliklerin tamamlanması ile birlikte mahalli idareler doğrudan sukuk ihracını gerçekleştirebilecektir. Bu hukuki eksikliklerin tamamlanması ile mahalli idareler iki farklı model ile sukuk ihracı gerçekleştirebilir. Bunlar; mahalli idarelerin gayrimenkul yatırım ortaklıkları (GYO) eliyle sukuk ihracı ve mahalli idarelerin doğrudan sukuk ihracı şeklinde olabilmektedir (Acar, 2019).

\subsubsection{Mahalli İdarelerin GYO Eliyle Sukuk İhract}

Önerilen bu modelde; sukuk ihrac1, mahalli idarelerin hukuki olarak doğrudan sukuk ihracı gerçekleştirememesi nedeniyle, mahalli idare tarafından kurulacak GYO vasıtasıyla gerçekleştirilecektir. Mevcut hukuki durumda mahalli idareler GYO kurarak altyap1 yatırımlarını bu GYO vasıtasıyla yürütebilmektedir. Modelde bir mahalli idarenin altyapı yatırımı gerçekleştirebilmesi için hukuki bir irade gereksinim bulunmaktadır. Bu da mahalli idarelerin karar organı, yerel yönetim meclisidir. Belediye meclisi bu yatırım projesi ve finansmanı için karar yetkisi almakla işe başlamaktadır. Sukuka konu yatırım, mahalli idarenin o yılki yatırım programında yer almalıdır. Sonrasında bu borçlanmanın oluşturulması, mahalli idareye izin ve yetki verilmesi için borçlanma talebi Çevre ve Şehircilik Bakanlığı'na bağlı bir birim olan Yerel Yönetimler Genel Müdürlüğ̈̈’ne gönderilecektir. Yüksek tutarda borçlanma olacağından Yerel Yönetimler Genel Müdürlüğü tarafından ilgili proje hakkında Cumhurbaşkanlığı Strateji ve Bütçe Başkanlığı'ndan uygun görüş istenecektir. Strateji ve Bütçe Başkanlığı izni verilebilmesi için kamu mali disiplinin sağlanması amacıyla KÖI'nde olduğu gibi 5 yıllık Stratejik Plan içinde yer alıp almadığına, ülke kalkınması için öncelikli olup olmadığına bakılacaktır. Daha sonra Strateji ve Bütçe Başkanlı̆̆ı'nın sukuk ihracı yöntemi ile finanse edilmesi yönünde uygun görüşünü vermesi halinde diğer aşamaya geçilebilecektir. Onayın alınmasının ardından Sermaye Piyasası Kurulu (SPK), Borsa İstanbul A.Ş.(BİST) ve şeri olarak da Diyanet İşleri Başkanlığı gibi bağımsız ve denetleyici kuruluşların incelemelerinin tamamlanması ve tamamının onayı alınması gerekmektedir (Acar, 2019).

Yerel Yönetimler Genel Müdürlüğü tarafindan tamamlanan incelemelerin olumlu sonuçlanması durumunda, proje ve finansman metodu İçişleri Bakan'ının uygun görüşüne sevk edilmesinden sonra son olarak Cumhurbaşkanın olurlarına sunulacaktır. Bu prosedürler her ne kadar uzun gibi gözükse de mahalli idareler kanunun amir hükmü gereğince bütçelerinin \% 10 'u aşacak borçlanmaların tamamında aynı metodu izlemek zorundadır. Cumhurbaşkanlığı hükümet sistemine geçilmeden önce mahalli idarelerin şirket kurma yetkisi Bakanlar Kurulu onayına tabiydi ancak cumhurbaşkanlığı hükümet sistemi ile birlikte Bakanlar Kurulunun kaldırılmasıyla birlikte bu yetki Cumhurbaşkanlığına verilmiştir. Bu nedenle yeni kurulacak GYO Cumhurbaşkanının onayı halinde kurulacak ve yine Cumhurbaşkanının son onayı ile birlikte sukuk ihraç işlemine başlanabilecektir. İlgili konuda Cumhurbaşkanının onayının alınması halinde ticaret sicile başvurularak ilgili mahalli idarenin iştirakleri arasında GYO kurulması sağlanacaktır. GYO'nun yöneticilerinin mahalli idarece atanmasına müteakip, mahalli idare, Varlık Kiralama Şirketi (VKŞ) kurularak doğrudan sukuk ihraç işlemleri için BİST'e başvurabilecektir (Acar, 2019).

Proje için gerekli izinlerin ve uygun görüşlerin tamamlanmasından sonra finansman için gerekli izinlerin alınması aşamasına geçilmelidir. Dünya sukuk ihraç örneklerine incelendiğinde, sukuk ihraçlarının tamamının özel sermaye şirketleri (SPV'ler) aracılığıyla yapıldığı görülmektedir. Türkiye'de aynı işlem için (VKŞ) kurulması gerekmektedir. Yurt içi sukuk ihraçlarında işlemler de VKŞ üzerinden gerçekleştirilebilir (Acar, 2019). 
Tuna ve Bostanc1 / Mahalli İdarelerde Altyapı Yatırımlarının Finansman Yöntemleri: Ankara Su ve Kanalizasyon İdaresi (ASKİ) Genel Müdürlüğü Örneği / Financial Instruments of Infrastructure Investments in Local Administrations: The Case of Ankara Water and Sewerage Administration (ASKI) General Directorate

\subsubsection{Mahalli İdarenin Doğrudan Sukuk İhracı}

Türkiye'de mahalli idarelerin mevcut yasal mevzuatta doğrudan sukuk ihraç edebilmesinin olanağı bulunmamaktadır. Fakat mahalli idareler kanunları ile kira sertifikaları mevzuatında birtakım değişikliklerin yapılması ile mahalli idarelerin sukuk ihraçları mümkün olabilecektir. Hukuki olarak TBMM tarafından mahalli idare kanunlarında değişiklikler yapılarak sukuk veya kira sertifikasına borçlanma başlığı altında bir finansman metodu olarak yer verilmesi gerekmektedir. Mahalli idarelerin sukuk ihraçları hakkında yasal düzenlemelerin yapılması ile birlikte sukuk ihraçlarını üç farklı VKŞ ile yürütebilmektedir. Bunun başında mahalli idarelerin kamu kurumu olması nedeniyle Hazinenin sukuk ihraçlarında kullandığı, Hazine Varlık Kiralama A.Ş. (HVKŞ)'i kullanılabileceği gibi, bir diğer alternatifte İlbank'a ait İlbank VKŞ kurulması ve sukuk ihraçlarına aracılık etmesi yasal olarak mümkün olacaktır (Acar, 2019).

İlbank'ın bir finans kurumu olması nedeniyle VKȘ kurması ile ilgili yasal bir engel bulunmamaktadır. Aksine mahalli idarelerin sukuk ihraçlarında kefalet verebileceğinden ve merkezi yönetim tarafindan aktarılan tüm gelirlerin İlbank eliyle dağıtılması sebebiyle VKȘ kurulması, ihracın bu VKŞ üzerinden yapılması ve ihraç edilecek sukuka kefalet vermesi gayet uygun olacaktır. Yine Katılım Bankaları aracılığıyla da sukuk ihracı yapılması da mümkündür. Özel sektöre ait bütün sukuk ihraçları yine Katılım Bankalarına ait VKŞ'ler aracılığıyla gerçekleştirilebilir (Acar, 2019).

\section{Ankara ASKİ Genel Müdürlüğü Örneği}

$\mathrm{Bu}$ bölümde ASKİ Genel Müdürlüğü örnek olarak incelenmiştir. ASKİ Genel Müdürlüğü'nün 2020 yılı altyapı yatırımları incelenmiştir (Tablo 5). 2014, 2015, 2016, 2017 yılları, 2018 y1lı ve 2019 y1lı 6 yıllık bütçe gelir ve giderleri incelenmiştir (Tablo 6, Tablo 7, Tablo 8, Tablo 9). 2020 yılı kesin hesabı henüz Ankara Büyükşehir Meclisince onaylanmadığ için 2020 yılına yer verilememiştir. Mahalli idare ve bağlı kuruluşlarında bütçe gelirleri bütçe giderlerini karşılayamamaktadır. 2019 yılı bütçe gideri 2.809.552.916,07 TL, bütçe geliri 2.531.662.310,37 TL'dir. Bütçe gelir gider fark1 -274.266.275,33 TL'dir (Tablo 8). ASKİ Genel Müdürlüğü 2020 yılı performans programı ve faaliyet raporu incelendiğinde yapılacak olan altyapı programında bütçe içinden kaynak oluşturulduğu görülmekte olup, bütçe dışından kaynak oluşturulmamıştır. 
Tablo 5. ASKİ Genel Müdürlügü 2020 yılı altyapı yatırımları

\begin{tabular}{|c|c|c|c|}
\hline \multirow[b]{2}{*}{ ASKI'nin faaliyeti } & \multicolumn{3}{|c|}{ ASKI'nin kaynak ihtiyacı } \\
\hline & Bütçe & $\begin{array}{c}\text { Bütçe } \\
\text { dış1 }\end{array}$ & Toplam \\
\hline Kullanma ve içme suyu şebeke hattı & $281.710 .000,00$ & 0,00 & $281.710 .000,00$ \\
\hline Kullanma ve içme suyu iletim ve isal hattı & $73.568 .000,00$ & 0,00 & $73.568 .000,00$ \\
\hline Kullanma ve içme suyu su deposu & $11.851 .000,00$ & 0,00 & $11.851 .000,00$ \\
\hline $\begin{array}{l}\text { Pompa istasyonları, arıtma tesisleri, kullanma ve içme suyu } \\
\text { su depoları, hizmet binası bakımı, tamiri ve onarımı }\end{array}$ & $23.173 .000,00$ & 0,00 & $23.173 .000,00$ \\
\hline Kullanma ve içme suyu arıtma tesisleri & $13.834 .000,00$ & 0,00 & $13.834 .000,00$ \\
\hline Kullanma ve içme suyu pompa istasyonları & $27.789 .000,00$ & 0,00 & $27.789 .000,00$ \\
\hline Kullanma ve içme suyu barajları & $9.767 .000,00$ & 0,00 & $9.767 .000,00$ \\
\hline Kullanma ve içme suyu göletleri & $10.568 .000,00$ & 0,00 & $10.568 .000,00$ \\
\hline Kullanma ve içme suyu altyapı projeleri & $2.992 .000,00$ & 0,00 & $2.992 .000,00$ \\
\hline Depo ve pompa istasyonları projeleri & $1.581 .000,00$ & 0,00 & $1.581 .000,00$ \\
\hline Su arıtma tesisi projeleri & $1.931 .000,00$ & 0,00 & $1.931 .000,00$ \\
\hline Gölet ve baraj projeleri & $2.486 .000,00$ & 0,00 & $2.486 .000,00$ \\
\hline İçme suyu yatırımına gerekli olan kamulaştırmalar & $22.858 .000,00$ & 0,00 & $22.858 .000,00$ \\
\hline Hali hazırdaki hatların rehabilite edilmesi ve işletilmesi & $312.325 .000,00$ & 0,00 & $312.325 .000,00$ \\
\hline Küçük ölçekteki arıtma tesisleri & $9.500 .000,00$ & 0,00 & $9.500 .000,00$ \\
\hline $\begin{array}{l}\text { Membran arıtma tesisinde verimi düşmüş, ömrünü } \\
\text { tamamlamış tesislerin yenilenmesi ve kapasitenin artırılması }\end{array}$ & $6.040 .000,00$ & 0,00 & $6.040 .000,00$ \\
\hline $\begin{array}{l}\text { Pursaklar içme suyu arıtma tesisinde sodyum hipoklorit } \\
\text { üretim tesisi }\end{array}$ & $2.478 .000,00$ & 0,00 & $2.478 .000,00$ \\
\hline Atıksu altyapı projeleri & $3.687 .000,00$ & 0,00 & $3.687 .000,00$ \\
\hline Yağmursuyu altyapı projeleri & $2.587 .000,00$ & 0,00 & $2.587 .000,00$ \\
\hline Atıksu arıtma tesisi projeleri & $5.496 .000,00$ & 0,00 & $5.496 .000,00$ \\
\hline $\begin{array}{lllll}\begin{array}{l}\text { Kanalizasyon } \\
\text { işlemleri }\end{array} & \text { yatıımlarına } & \text { gerekli } & \text { olan } & \text { kamulaştırma } \\
\end{array}$ & $13.958 .000,00$ & 0,00 & $13.958 .000,00$ \\
\hline $\begin{array}{l}\text { Yerleşim yerlerinde atıksu debilerine ve nüfusa göre atıksu } \\
\text { arıtma tesislerinin yapımı }\end{array}$ & $40.507 .000,00$ & 0,00 & $40.507 .000,00$ \\
\hline $\begin{array}{l}\text { Ankara sınırlarındaki mahalle ve ilçelerin atıksu hatlarının } \\
\text { yapımı }\end{array}$ & 326.245.000,00 & 0,00 & $326.245 .000,00$ \\
\hline $\begin{array}{l}\text { Ankara sınırlarındaki mahalle ve ilçelerin yağmursuyu } \\
\text { hatlarının yapımı }\end{array}$ & $125.873 .000,00$ & 0,00 & $125.873 .000,00$ \\
\hline $\begin{array}{l}\text { Ekonomik ömrünü dolduran ve sık arızalanan altyapıları } \\
\text { yenilemek }\end{array}$ & $63.180 .000,00$ & 0,00 & $63.180 .000,00$ \\
\hline Mevcuttaki yağmursuyu ızgaralarının rutin temizliği & $15.400 .000,00$ & 0,00 & $15.400 .000,00$ \\
\hline Atıksu hatları temizlemek & $8.500 .000,00$ & 0,00 & $8.500 .000,00$ \\
\hline Toplam & 1.419 .884 .000 & & 1.419 .884 .000 \\
\hline
\end{tabular}

Kaynak: ASKİ Genel Müdürlüğ̈̈ (2021)

Toplam yatırım harcaması 1.419.884.000 TL olup, en yüksek harcama kalemleri arasında; Ankara sınırlarındaki mahalle ve ilçelerin atık su hatlarının yapımı işi (326.245.000,00 TL), mevcut hatların işletilmesi ve rehabilite edilmesi (312.325.000 TL), kullanma ve içme suyu şebeke hattı yapımı işi (281.710.000,00 TL) bulunmaktadır (Tablo 5). ASKİ Genel Müdürlügü̈'nün incelenen dönemdeki toplam yatırım harcaması içinde en yüksek payı \%23 ile Ankara sınırlarındaki mahalle ve ilçelerin atık su hatlarının yapımı işi almakta ve kurumun atık su arıtma yatırımlarına mümkün olduğunca fazla yatırım yaparak kentin su kaynaklarının korunması ve atık suların arıtma sonrası yeniden kullanımına ilişkin faaliyetleri ile sürdürülebilir kentsel gelişme ve yerel sürdürülebilirlik göstergelerine önemli ölçüde katk1 yapmaktadır.

ASKİ Genel Müdürlügü 2020 y1lı toplam bütçesi 3.422.000.000,00 TL ve toplam bütçesi içindeki yatırım harcamalarının oranı \%41 olarak tahmin edilmiştir. Kurumun yıllık bütçesinin neredeyse yarısını yatırım harcamaları kaleminin oluşturduğu ve yatırım 
Tuna ve Bostancı / Mahalli İdarelerde Altyapı Yatırımlarının Finansman Yöntemleri: Ankara Su ve Kanalizasyon İdaresi (ASKİ) Genel Müdürlügü Örneği / Financial Instruments of Infrastructure Investments in Local Administrations: The Case of Ankara Water and Sewerage Administration (ASKI) General Directorate

harcamalarının bütçe içi kaynaklardan karşılandığı görülmektedir (Tablo 5). Kurumun bütçe içi olanaklarla kentin uzun dönemde içme ve kullanma suyu yatırımları ile kanalizasyon, yağmur suyu toplama ve atıksu arıtma çalışmalarını finanse etmesi ve özellikle iklim değişikliği ve kuraklık gibi yakın tehlikelerin etkileri de dikkate alındığı zaman oldukça güç görünmektedir. Kurumun başka bir çalışma konusu olan içme ve kullanma suyu ve kanalizasyon fiyatlama modeli ve tarife ile ilgili düzenlemeler de gelecek için fon oluşturma ve uzun dönemli yatırımlar için kaynak oluşturmaya yönelik hizmet fiyatlaması yapmaya olanak vermediğine dikkate edilmelidir.

Tablo 6. ASKİ Genel Müdürlüğü 3 yıllık bütçe gideri (2014-2016)

\begin{tabular}{lccc}
\hline & 2014 yıl1 & 2015 y1li & 2016 y1l1 \\
\hline Personel giderleri & $127.325 .684,13$ & 155.619 .474 & $150.525 .403,72$ \\
\hline $\begin{array}{l}\text { Sosyal güvenlik kurumunda devlet primi } \\
\text { giderleri }\end{array}$ & $21.512 .185,19$ & $23.933 .719,87$ & $24.133 .282,45$ \\
\hline Mal ve hizmet alım giderleri & & & \\
\hline Faiz giderleri & $519.290 .941,47$ & $1.092 .339 .477,50$ & $667.296 .226,74$ \\
\hline Cari transferler & $11.896 .344,43$ & $24.711 .476,78$ & $15.975 .454,19$ \\
\hline Sermaye giderleri & $14.064 .024,31$ & $17.523 .523,31$ & $20.209 .468,49$ \\
\hline Borç verme & $594.841 .870,89$ & $861.804 .495,96$ & $590.616 .810,40$ \\
\hline Toplam & $144.746 .750,00$ & 89.995 .800 & 550.000 .000 \\
\hline
\end{tabular}

Kaynak: ASKİ Genel Müdürlüğ̈̈ (2017)

Örnek olarak incelenen kurumun yatırım giderleri (altyapı yatırımları) sermaye giderleri içerisinde yer almaktadır. Kurumun yatırım giderleri, 2014 yılı 594.841.870,89 TL, 2015 yılı 861.804.495,96 TL ve 2016 yıl1 590.616.810,40 TL olarak gerçekleşmiştir. 2015 yılında sermaye gideri 2014 yılına kıyasla artış göstermiştir (Tablo 6)

Tablo 7. ASKİ Genel Müdürlüğü 3 yıllık bütçe gideri (2017-2019)

\begin{tabular}{lccc}
\hline & 2017 y1l1 & 2018 y1l1 & 2019 y1l1 \\
\hline Personel giderleri & $129.399 .015,87$ & $139.195 .314,98$ & $176.296 .582,41$ \\
\hline Sosyal güvenlik kurumunda devlet primi giderleri & $22.229 .771,79$ & $24.205 .706,18$ & $29.773 .924,33$ \\
\hline Mal ve hizmet alım giderleri & $791.840 .016,82$ & $939.748 .693,50$ & $836.482 .822,84$ \\
\hline Faiz giderleri & $16.449 .383,53$ & $7.739 .462,59$ & $4.399 .835,21$ \\
\hline Cari transferler & $138.986 .305,50$ & $267720.646,50$ & $135.905 .124,35$ \\
\hline Sermaye giderleri & $625.828 .301,82$ & $837.588 .758,52$ & $1.476 .694 .626,93$ \\
\hline Borç verme & $700.000 .800,00$ & $664.880 .000,00$ & $150.000 .000,00$ \\
\hline Toplam & $2.424 .733 .595,33$ & $2.881 .078 .582,27$ & $2.809 .552 .916,07$ \\
\hline
\end{tabular}

Kaynak: ASKİ Genel Müdürlüğ̈̈ (2019)

İncelenen kurumun yatırım giderleri, 2017 y1l $625.828 .301,82 \quad \mathrm{TL}, 2018$ y1l1 837.588.758,52 TL ve 2019 y1l1 1.476.694.626,93 TL olarak gerçekleşmiş (Tablo 7) olup, cari fiyatlarla yatırım giderleri kaleminin sürekli artış eğiliminde olduğu görülmektedir. Ancak belirtilen bütçe ile kentin yıllarca birikmiş olan altyapı inşaatı ve mevcut altyapı yatırımlarının yenilenmesinin kısa ve orta vadede tamamlanması mümkün görülmemektedir. Yerel düzeyde su ve kanalizasyon gibi altyapı yatırımlarının sadece bütçe olanakları finanse edilmesi ve bu yolla yerel halkın gereksinimlerinin karşılanması mümkün olamamaktadır. Bu koşullarda altyapı yatırımları için mevzuatta tanımlanan harcamalara katılım payının hesaplanması ve tahsil yöntemlerinin iyileştirilmesi, Aliefendioğlu ve Tanrıvermiş (2011), Aliefendioğlu ve Bostanc1 (2018) , Ünal ve Tanrıvermiş (2019), Ünal (2021), gibi araştırmacılar tarafından önerildiği gibi, mahalli idarelerce sunulan altyapı hizmetlerinin ve özellikle su ve kanalizasyon hizmetlerinin fiyatlanmasına sabit ve değişen masraflar ile yatırım fonu tesisi için kullanıcılardan uygun payının alınmasına dayalı modellerin geliştirilmesi, su havzalarının yönetiminde yönetim anlaşmaları ve boş bırakma politikalarının değerlendirilmesi, gelir getirici faaliyetlere ağırlık verilmesi ve mevcut gayrimenkullerin varlık yönetimi ve kurumsal sosyal sorumluluk içinde değerlendirilmesi, metro ve dönüşüm projelerinin neden olabileceği değer artışının proje finansmanında kullanım olanaklarının analiz edilmesi ve bu yönde mevzuatta gerekli düzenlemelerin yapılması zorunluluğu ortaya çıkmaktadır. 
İncelenen kurumun 2014 y1lı bütçe gideri 1.433.677.800,42 TL, bütçe geliri 1.462.808.513TL ve bütçe gelir-gider fark1 ise 29.130.712,64 TL olarak gerçekleşmiştir. 2015 yılı bütçe gideri 2.265.927.967,42 TL, bütçe geliri 1.964.334.537 TL ve bütçe gelir gider fark1 301.593.430,40 TL, 2016 y1lı bütçe gideri 2.018.756.645,99TL, bütçe geliri 2.131.453.239 TL ve bütçe gelir-gider farkı ise 112.696.593 TL olarak gerçekleşmiştir (Tablo 8). İncelenen dönemde bütçe gelir-gider farkının pozitif olduğu, ancak çoğunluğu gayrimenkul kira gelirlerinden oluşan sermaye gelirlerinin 2014 ve 2015 yıllarında olmaması dikkati çekici olarak görülmektedir.

Tablo 8. ASKİ Genel Müdürlüğü 3 yıllık bütçe geliri (2014-2016)

\begin{tabular}{llll}
\hline & 2014 y1l & 2015 y1l1 & 2016 y1l1 \\
\hline Teşebbüs ve mülkiyet gelirleri & $1.281 .618 .900,70$ & $1.696 .833 .453,09$ & $1.876 .326 .130,49$ \\
\hline Diğer gelirler & $185.899 .491,33$ & $208.283 .706,78$ & $243.651 .143,49$ \\
\hline Sermaye gelirleri & 0 & 0 & $26.294 .260,36$ \\
\hline Alacaklardan tahsilat & $1.638 .880,00$ & $69.861 .376,15$ & $9.388 .672,17$ \\
\hline Bütçe gelirlerinden ret ve iadeler (-) & $6.348 .758,97$ & $9.643 .999,04$ & $24.206 .967,50$ \\
\hline Bütçe gelir & 1.462 .808 .513 & 1.964 .334 .537 & 2.131 .453 .239 \\
\hline Bütçe gideri & $1.433 .677 .800,42$ & $2.265 .927 .967,42$ & $2.018 .756 .645,99$ \\
\hline Bütçe gelir gider fark1 & $29.130 .712,64$ & $-301.593 .430,40$ & 112.696 .593 \\
\hline
\end{tabular}

Kaynak: ASKİ Genel Müdürlüğü (2017)

Kurumun 2019 yılı bütçe gideri 2.809.552.916,07 TL, bütçe geliri 2.531.662.310,37 TL ve bütçe gelir-gider farkı ise -274.266.275,33 TL olarak gerçekleşmiş olup, bütçe gelirleri ile bütçe giderlerinin karşılanamadığı görülmektedir (Tablo 9). Gerek incelenen kurumda, gerekse birçok mahalli idare biriminin benzer kurumunda gelir-gider farkının menfi olduğu dikkati çekmekte olup, mevcut koşullarda incelenen kurum gibi önemli altyapı yatırımları yapan idarelerin kaynak yetersizliği sorunlarının olduğu ve kaynak geliştirme konusunda kalıcı çözüm yollarının bulunması konusunda yeterince çalışmanın yapılamadığı anlaşılmaktadır. İncelenen kurum gibi genellikle altyapı yatırımı yapan idarelerin mutlaka gelir getirici faaliyetlerle kaynak oluşturması, yeni hizmet fiyatlama modeline geçmeleri, sermaye maliyetleri dahil toplam işletme giderleri üzerinden hizmetlerin fiyatlanması, içme suyu toplama havzalarında kullanımı kısıtlanan parsellerin maliklerinin el atma davaları ve tazminat yükünü azaltacak yönetim anlaşmaları ve kiralama gibi yöntemlerin geliştirilmesi (Aliefendioğlu ve Tanrıvermiş 2011, Tanrıvermiş 2019) ve sürdürülebilirlik hedeflerine daha yüksek düzeyde katkı yapabilecek yatırım ve yönetim modellerinin geliştirilmesine gereksinim bulunmaktadır.

Tablo 9. ASKİ Genel Müdürlügü 3 yıllık bütçe geliri (2017-2019)

\begin{tabular}{cccc}
\hline & 2017 y1l1 & 2018 y1l1 & 2019 y1l \\
\hline Teşebbüs ve mülkiyet gelirleri & $2.250 .622 .330,98$ & $2.485 .001 .564,91$ & 1.897 .207 .096 .59 \\
\hline Diğer gelirler & $271.609 .510,32$ & $357.709 .547,92$ & $305.011 .796,82$ \\
\hline Sermaye gelirleri & $138.764 .737,09$ & $147.513 .335,46$ & 0,00 \\
\hline Alacaklardan tahsilat & $11.039 .138,14$ & $10.891 .298,56$ & $333.067 .747,33$ \\
\hline Bütçe gelirlerinden ret ve iadeler (-) & $9.013 .623,46$ & $10.198 .522,30$ & $3.624 .330,37$ \\
\hline Bütçe gelir & $2.663 .022 .093,07$ & $2.990 .917 .224,55$ & $2.531 .662 .310,37$ \\
\hline Bütçe gideri & $2.424 .733 .595,33$ & $2.881 .078 .582,27$ & $2.809 .552 .916,07$ \\
\hline Bütçe gelir gider fark1 & $238.288 .497,74$ & $109.838 .642,28$ & $-274.266 .275,33$ \\
\hline & Kaynak: ASKİ Genel Müdürlüŭ̈̈̈ (2019)
\end{tabular}

Altyapı yatırımları sermaye giderleri içinde yer aldığı için 2019 sermaye giderleri incelenmiştir: 2019 Sermaye giderleri gerçekleşmenin bütçeye oranı \%87,71 iken, toplam gerçekleşme içindeki oranı \%52,56 olmuştur (Tablo 10). 2019 gelir bütçesi gerçekleşmesinde gerçekleşmenin bütçeye oranı \%66,62 olup, bu durum gelir bütçesi yapılmasında tam olarak gerçekleşme tahmininin yapılmadığını göstermektedir. 
Tuna ve Bostancı / Mahalli İdarelerde Altyapı Yatırımlarının Finansman Yöntemleri: Ankara Su ve Kanalizasyon İdaresi (ASKİ) Genel Müdürlügü Örneği / Financial Instruments of Infrastructure Investments in Local Administrations: The Case of Ankara Water and Sewerage Administration (ASKI) General Directorate

\begin{tabular}{lcccc}
\hline \multicolumn{4}{c}{ Tablo 10. ASKİ Genel Müdürlüğü 2019 y1l sermaye giderleri gerçekleme oranı } \\
\hline & Bütçe & Gerçekleşme & $\begin{array}{c}\text { Gerçekleşmenin bütçeye } \\
\text { oran1 \% }\end{array}$ & $\begin{array}{c}\text { Toplam gerçekleşme } \\
\text { içindeki oran } \%\end{array}$ \\
\hline $\begin{array}{l}\text { Sermaye } \\
\text { giderleri }\end{array}$ & $1.683 .553 .282,65$ & $1.476 .694 .626,93$ & 87,71 & 52,56 \\
\hline
\end{tabular}

Kaynak: ASKİ Genel Müdürlüğü (2020)

İnceleme sonuçlarına göre genel olarak mahalli idarelerin ve özellikle su ve kanalizasyon ile ulaşım gibi büyük altyapı yatırımları yapan kurumların kaynak geliştirme, hizmet fiyatlama ve klasik yönetim yaklaşımından modern varlık yönetimi modeline geçmelerine gereksinim bulunmaktadır. Birçok büyükşehir belediyesi su ve kanalizasyon idaresinin su havzalarının korunması ve kaynak tedarikinde önemli kamulaştırma ve el atma tazminatı ödediği ve arazi edinimi ve yönetimi modelinin geliştirilemediği dikkati çekmektedir. Bunun en önemli örneklerinden birini kamulaştırma işlemleri tamamlanmadan inşa edilerek kullanıma açılan, Kesikköprü Barajı ile İvedik İçme Suyu Arıtma Tesisi arasında inşa edilen ve her biri $128 \mathrm{~km}$ uzunluğunda toplam $384 \mathrm{~km}$ 'lik üç ayrı boru hattı yatırımı olarak gösterilebilir. İnşaatı 2009 yılında tamamlanan boru hattı ihtiyaç duyulması halinde kullanıma alınmakta olup, henüz hattın güzergahında kalan özel mülkiyete konu arazilerin kamulaştırma işlemleri tamamlanamamış, her yıl el atma tazminatları ödenmekte ve yatırım güzergahının hatalı olması ve uygun boru tipinin seçilememiş olmasının neden olduğu patlama ve kazalardan dolayı da her yıl önemli tutarda tazminatların ödenmesi kaçınılmaz olmaktadır.

Yatırımcı ve diğer yerel yönetim kurumlarında proje geliştirme, arazi edinimi, kamulaştırma ve gayrimenkul yönetimi konularında önemli sorunların olduğu ve mevcut insan kaynağı ile bu sorunlara çözüm bulunmasının oldukça güç olduğu açıktır. Birçok mahalli idare biriminde Kesikköprü Barajı ile İvedik İçme Suyu Arıtma Tesisi gibi içme suyu ve kanalizasyon, arıtma, otobüs terminali, tramvay ve metro yatırımına rastlanmakta ve hatalı yatırım kararı veren ve seçimle işbaşına gelen yerel idare yöneticileri de genellikle hesap vermemekte, yatırım kararlarında rasyonellik ve şeffaflık yüksek düzeyde olduğu için uygun koşullarda ve düşük faizli kredi bulma olanakları da genellikle mümkün olamamaktadır. Belirtilen sorunların asgari düzeye çekilmesi için bir yandan mevcut işgücüne yatırım yapılması ve diğer yandan da 5393 sayılı Belediye Kanununun 49'uncu maddesindeki norm kadroda yer alacak mesleklerin gözden geçirilmesi ve yukarıda belirtilen hatalı yatırım kararları ve oluşan kamu zararlarının asgari düzeye çekilmesini sağlamak üzere norm kadroda üniversitelerin gayrimenkul geliştirme ve yönetimi bölümlerinden mezun olan uzmanların istihdamına önem ve öncelik verilmesi zorunlu görülmektedir. Mevcut koşullarda incelenen kurum gibi altyap1 idarelerinde inşaat, yatırım geliştirme, kamulaştırma ve mali hizmetler gibi birimlerde istihdam edilen personelin eğitim-öğretimi ve mesleki konuları arasında belirtilen konuların olmadığı ve bu konuların sadece üniversitelerin gayrimenkul geliştirme ve yönetimi bölümlerinin lisans ve lisansüstü programlarında ele alındığ 1 vurgulanmalıdır. Kurumların insan kaynaklarının nitelik ve veriminin artırılması için personel rejiminin gözden geçirilmesi ve yasal düzenleme yapılmasına gereksinim bulunmaktadır.

İncelenen kurum ve benzer yerel yönetim birimlerinde tesis ve gayrimenkul yönetimi, yatırım analizi, proje finansmanı ile proje ve yapım yönetimi konusunun yeniden ele alınması gerekmektedir. Mevcut koşullarda yerel yönetim kurumları bütçe olanakları ve genellikle yüksek maliyetli borçlanma ile yatırımları finanse etme gibi geleneksel yöntemleri kullanma eğilimindedirler. Bu koşullarda gerek bir bütün olarak mahalli idarelerin faaliyetleri, gerekse özel olarak altyapı yatırımlarının finansmanı için proje finansmanı modellerinin geliştirilmesi (yap-işlet-devret, yap-kirala-işlet-devret gibi), tahvil ve gelir ortaklığı senedi ihracı, GYO kuruluşu, gayrimenkul ve kira sertifikas1, sukuk ve diğer İslami finans ürünlerinin ihrac1 olanaklarının tesis edilmesi ve buna yönelik mevzuatta ve kurumsal yapıda düzenleme yapılması gerektiği ortaya çıkmaktadır. Ancak yerel yönetimlerde proje geliştirme, proje finansmanı ve belirtilen diğer yeni finansman araçlarının başarılı olarak uygulanabilmesi için 5393 Sayılı Kanunun 41'inci maddesine göre tesis edilecek norm kadroda mutlaka yukarıda 
belirtilen bölümlerden mezun olan uzmanların da yer almalarının sağlanması ve ayrıca yerel yönetimlerde proje finansmanı ve alternatif yatırım finansman modellerinin geliştirilmesine ilişkin yasal altyapının iyileştirilmesi, işleyişin kolaylaştırılması ve sürecin şeffaflaştırılmasına da gereksinim olacağı vurgulanmalıdır.

\section{Sonuç ve Öneriler}

Kamu idarelerinde altyapı finansmanında kullanılan yöntemlerin sınırlı olması, bütçenin yeterli olmaması, halkın yerel yönetimin sunduğu hizmetleri nitelik ve nicelik bakımından sorgulaması, kamuoyunun ekonomik politikalar ile ilgili gelişmeleri duyarlılıkla izlemesi, kamu harcamalarının artması gibi gelişmeler, kamuda yöneticilerin görev ve sorumluklarının artmasına sebep olmuştur. Birçok merkezi ve mahalli idare birimlerinin yeni kaynak arayışlarına yöneltmiş oldukları görülmektedir. Buna ilave olarak son yıllarda kamu mali yönetimi konusunda meydana gelen yeni anlayış, kamu kaynaklarının daha etkili, verimli, ekonomik ve performans geliştirici şekilde kullanılmasını zorunlu kılmıştır. Hem görev ve sorumlulukların artmasının etkisi, hem de uluslararası organizasyonlar ve yasal zorunluluklar gereğince son zamanlarda birçok devlet, kurumlarının idari yapılarını geliştirmek için çalışmalar yapmaktadır.

Ulaştırma, haberleşme, kentsel altyapı, sağlık, eğitim gibi altyapı yatırımlarının kapasite artırıcı, gelir artırıcı ve ekonominin yapısal değişimine etkileri bulunmaktadır. Gelişmekte olan ülkelerde asgari düzeyde altyapı yatırımlarının yapılması ve belirli seviyede kent halkına hizmet sunulması zorunlu görülmektedir. Sürdürülebilirlik hedefleri ve yaşam kalitesini yükseltme hedefleri, daha fazla altyapı ve üstyapı yatırımlarının gerçekleştirilmesini zorunlu kılmakta ve bunun için de çok yüksek tutarda sermaye yatırımlarının yapılmasına gereksinim olmaktadır. Ancak mahalli idarelerin bu altyapı yatırımlarını kendi öz kaynakları ile gerçekleştirmesi neredeyse imkânsız görülmekte ve yabancı sermaye kullanımı ile proje geliştirme ve uygulama yapılması zorunlu olmaktadır. Birçok belediyede ağılık kentsel dönüşüm projelerine verilmekte ve altyapı yatırımları da genellikle ihmal edilmekte, kuraklık, sel ve su baskını ve deprem gibi afetler yaşandığı zaman altyapı yatırımlarının gerekliliği anlaşılmaktadır. Ancak altyapı yatırım projelerinin geliştirilmesi, arazi edinimi ve finansman tedariki uzun zaman almakta, inşaat süresi ve maliyetleri yüksek olmakta, yatırım uzun vadeli ve yatırım geri dönüş süresi çok uzun olmakta ve belediyelerin mali yapıları uygun koşullarla yabancı kaynak kullanmaya imkân vermemektedir. Bunlara ilave olarak alternatif finansman araçlarının da geliştirilememiş olması gibi nedenlerle yüksek maliyetli altyapı yatırımları ya genellikle merkezi idare ve mahalli idarelerce finanse edilmekte ya da yatırım kararları sürekli olarak ertelenmektedir.

Merkezi idare ve yerel yönetimler altyapı yatırımlarını finansmanında aynı yöntemleri kullandığı gibi farklı yöntemleri de seçebilirler. Bu kaynaklardan en önemlisi borçlanmadır. Borçlanma konusu finansman kaynăg 1 benzer olabilir fakat borçlanma şekilleri ve borçlanma kaynakları değişiklik gösterebilir. Hem merkezi idare hem de yerel yönetimler iç ve diş borçlanma yapabilir. Merkezi hükümet Sosyal Güvenlik Kuruluşlarından iç borçlanma, Merkez Bankası'ndan, Devlet Tahvili ile, Hazine Bonosu ile; İslam Kalkınma Bankası, Uluslararası Kalkınma Ajansı, Asya Kalkınma Bankası gibi kuruluşlardan dış borçlanma gerçekleştirilebilir. Yerel yönetimler ise hazine garantili veya hazine garantisiz olarak dış borçlanma, ticari bankalardan ve İller Bankası'ndan tahvil ihracı şeklinde iç borçlanma yapabilmektedir. Örneğin İstanbul'da yerel yönetim kurumlarınca ulaştırma yatırımları genellikle Türk ve yabancı bankalardan borçlanma yoluna giderek finanse edilmektedir.

Altyapı yatırımlarında finansman sorunlarının yanı sıra başka sorunlar mevcuttur. Altyapı hizmetleri sunulurken yaşanmakta olan sorunlardan biri de yerel yönetimler seçimle iş başına geldikleri için belediye başkanları seçim odaklı çalışmaktadırlar ve altyapı yatırımlarından daha çok üst yapı yatırımlarıyla ilgilenebilmekte ve bazen önemli altyapı problemleri göz ardı edebilmektedirler. Başka bir sorun ise, yerel yönetimlerin borçlanma araçlarının kullanımı veya sermaye piyasası işlemlerinde yer alamamaktadır. Halbuki yerel yönetimler altyapı yatırımlarının finansmanında bu araçları kullanabilir. Bunun muhtemelen en 
Tuna ve Bostancı / Mahalli İdarelerde Altyapı Yatırımlarının Finansman Yöntemleri: Ankara Su ve Kanalizasyon İdaresi (ASKİ) Genel Müdürlügü Örneği / Financial Instruments of Infrastructure Investments in Local Administrations: The Case of Ankara Water and Sewerage Administration (ASKI) General Directorate

büyük sebebi yeterli ve yetişmiş insan kaynağının bulunmaması olabilir. Bu nedenle personel istihdamında bu durum gözetilmesi gerekmektedir. Altyapı yatırımları proje geliştirme, başarılı yönetim, uygun finans bulma ve rasyonel varlık yönetimi çalışmalarının yapılabilmesi için işgücüne yatırım yapılması ve mevcut işgücünün nitelik ve veriminin artırılması ve ayrıca ilgili birimlerde gayrimenkul geliştirme ve yönetimi ile ilgili diğer uzmanlık dallarının norm kadro kapsamına alınması zorunlu görülmektedir. Gelişmiş ülkelerin benzer kurumlarına bakıldığı zaman nitelikli işgücünün istihdamının başarının ilk şartı olduğu ve uzmanlığa önem verildiği dikkati çekmektedir.

Mahalli idarelere aktarılan kaynakların yeterli olmaması da altyapı hizmetlerinin sunumunu kısıtlayan bir etken olmaktadır. Altyapı yatırımlarının finansmanının sadece geleneksel yatırım finansmanı olarak ele alınması, kentlerin yeni altyapı yatırımları ve mevcut olanların da yenilenmesi ve yönetimi giderlerinin yüksekliği nedeni ile uygun bulunmamaktadır. $\mathrm{Bu}$ koşullarda yerel yönetimlerde proje finansmanı ve alternatif yatırım finansman modellerinin geliştirilmesine ilişkin yasal altyapının iyileştirilmesi, işleyişin kolaylaştırılması ve sürecin şeffaflaştırılmasına da gereksinim olacağı vurgulanmalıdır. İlk olarak su ve kanalizasyon idareleri ve daha genel olarak bütün yerel yönetim mevzuatının gözden geçirilmesi ve altyapı yatırımlarının finansmanı için proje finansmanı modellerinin geliştirilmesi (yap-işlet-devret, yap-kirala-işlet-devret gibi), tahvil ve gelir ortaklığı senedi ihracı, GYO kuruluşu, gayrimenkul ve kira sertifikası, sukuk ve diğer İslami finans ürünlerinin ihracı olanaklarının tesis edilmesi gerekli görülmektedir. Belirtilen finansman araçları ve yöntemlerinden büyük ölçüde belirli bir kapasiteye sahip olan büyük kentlerin daha fazla yararlanma olanaklarının olacağı ve buna yönelik mevzuatta ve kurumsal yapıda düzenleme yapılması gerektiği ortaya çıkmaktadır. Diğer il, ilçe ve belde belediyeleri için başta İlbank olmak üzere yatırım geliştirme ve destek programlarının hazırlanması ve uygulanması zorunlu olacaktır.

Sonuç olarak mahalli idarelerin su ve kanalizasyon gibi altyapı yatırımlarını yalnızca kendi bütçe imkanları ile finanse edilmesi ve bu yöntemle vatandaşların gereksinimlerinin karşılanması mümkün gözükmemektedir. Bu şartlarda altyapı yatırımlarının finansmanı için harcamalara katılım payının hesaplanması ve tahsil yöntemlerinin daha da iyileştirilmesi, altyapı hizmetlerinin fiyatlanmasına sabit ve değişen masraflar ile yatırım fonu tesisi için kullanıcılardan pay alınmasına dayalı modellerin geliştirilmesi, gelir getirici faaliyetlere ağırlık verilmesi ve mevcut gayrimenkullerin varlık yönetimi ve kurumsal sosyal sorumluluk içinde değerlendirilmesi ve bu yönde mevzuatta gerekli düzenlemelerin yapılması gerekliliği ortaya çıkmaktadır.

\section{Kaynakça}

Acar, V. (2019). Yerel yönetimlerin alt yapı yatırımlarının finansmanında alternatif bir yöntem olarak sukuk ve bir model önerisi. (Yüksek lisans tezi). Balıkesir Üniversitesi Sosyal Bilimler Enstitüsü, İşletme Ana Bilim Dalı, Muhasebe ve Finansman Bilim Dalı, Balıkesir.

Akbulut, A. ve Tekeli, R. (2016). Mali özerk yerel yönetimlerde gelir kaynakları, Sivas Cumhuriyet Üniversitesi Sosyal Bilimler Dergisi, 40(1), 351-369.

Aktan, C. C. ve Dileyici, D. (2005). Genel olarak altyapı hizmetleri, C. C. Aktan, D. Dileyici, İ. Y. Vural (ed.) içinde, ss. (11-19). Ankara: Seçkin Yayınları.

Aktan, C. C., Dileyici, D. ve İstiklal, V. (2010). Altyapı ekonomisi, altyapı hizmetlerinde serbestleşme ve özelleştirme, Ankara: Seçkin Yayınları.

Aliefendioğlu, Y. ve Bostancı, S. (2018). Yerel yönetimlerde raylı sistem yatırımlarının yapılabilirliği: Ankara Büyükşehir Belediyesi Batıkent-Sincan-Törekent Metro Hattı örneği, Sosyal Bilimler Dergisi, 5(21), 117-142.

Aliefendioğlu, Y. ve Tanrıvermiş, H. (2011). Türkiye'de çevre koruma alanlarında arazi kullanımı ve koruma kararlarının arazi piyasalarına etkileri: Gökova Özel Çevre Koruma 
Bölgesi örneği, Üçüncü Sektör Kooperatifçilik (Yeni ismiyle Üçüncü Sektör Sosyal Ekonomi Dergisi), 46(1), 64-102.

Ankara Su ve Kanalizasyon İdaresi (ASKİ) Genel Müdürlüğü (2017). 2016 yıll faaliyet raporu. https://www.aski.gov.tr/TR/Anasayfa. (Erişim Tarihi: 10.02.2021).

Ankara Su ve Kanalizasyon İdaresi (ASKİ) Genel Müdürlüğü (2019). 2018 yılı faaliyet raporu. https://www.aski.gov.tr/TR/Anasayfa. (Erişim Tarihi: 12.02.2021).

Ankara Su ve Kanalizasyon İdaresi (ASKİ) Genel Müdürlüğü (2020). 2019 yılı faaliyet raporu. https://www.aski.gov.tr/TR/Anasayfa. (Erişim Tarihi: 12.02.2021).

Ankara Su ve Kanalizasyon İdaresi (ASKİ) Genel Müdürlüğü (2021). 2020 yılı faaliyet raporu. https://www.aski.gov.tr/TR/Anasayfa. (Erişim Tarihi: 20.02.2021).

Aschauer, D. A. (1989). Is public expenditure productive? Journal of Monetary Economics,23(2), 177-200.

Bozlağan, R. (2003). Kamu yönetimi paradigmasında değiş̧im ve özelleştirme yaklaşımı. Acar, M. ve Özgür, H. (Ed), Çağdaş kamu yönetimi içinde (ss. 278-196). Ankara: Nobel Yayın Dağıtım.

Çetin, V. R. ve Irmak, I. (2012). Posta hizmetlerinin ekonomisi ve regülasyonu. İstanbul: Rakun Matbaacilik.

Çetinkaya, Ö. (2015). Mahalli idareler maliyesi (5.Bask1). Bursa: Ekin Kitapevi.

Dinçsoy, S. (2001). Belediye Tahvilleri (Municipal Bonds) Kavramı ve Mahalli İdareler Tarafindan İhraç Edilebilecek Sermaye Piyasası Üzerine Öneriler. Sermaye Piyasası Kurulu Ortaklıklar Finansmanı Dairesi, Yeterlilik Etüdü.

Ertan, B. (2002). Yerel yönetim kavramı, Çağdaş Yerel Yönetimler Dergisi, 11(1), 22-30.

Farhadi, M. (2015). Transport infrastructure and long-run economic growth in OECD countries. Transportation Research Part A: Policy and Practice, 74(4), 73-90.

Finger, M., Groenewegen, J., \& Künneke, R. (2005). The quest for coherence between institutions and technologies in infrastructures. Journal of Network industries, 6(4), 227-259.

Hazine ve Maliye Bakanlığı Muhasebat Genel Müdürlüğü (2020). https://ms.hmb.gov.tr/ uploads/sites/3/2019/02/ 2016Y\%C4\% B11\%C4\%B1-Mali-Analiz-Raporu.pdf. （Erişim Tarihi: 05.02.2021).

ISPAT (2018). T.C. Başbakanlık Türkiye Yatırım Destek ve Tanıtım Ajansı https://www.igcturkey.com/tr/news/tc-basbakanlik-turkiye-yatirim-des tek-ve-tanitim-ajansi-ispat-igcturkiye 2018i-destekleme. (Erişim Tarihi:20.02.2021).

İlbank (2020). Illbank 30 Eylül 2020 Dönemine Ait Konsolide Olmayan Finansal Tablolar ve Sinirl Denetim Raporu. https://www.ilbank.gov.tr/storage/uploads/reports /iller-bankasi30092020-bdr.pdf. (Erişim Tarihi: 05.02.2021).

Kamu Kurum ve Kuruluşlarının Hazine Garantisi Olmaksızın Hibe Hariç Dış İmkân Sağlanmasına İzin Verilmesine ve Sağlanan Dış İmkânın İzlenmesine İlişkin Yönetmelik, (2009).https://mevzuattakip.com.tr/mevzuat/kamu-kurum-ve-kuruluslarinin-hazine-garantisi -olmaksizin-hibe-haric-dis-imkan-saglamasina-izin-verilmesine-ve-saglanan-dis-imkanin-iz lenmesine-iliskin-yonetmelik. (Erişim Tarihi: 10.02.2021).

Karahanoğulları, O. (2013). Yerel özerklik: mahalli müşterek ihtiyaçların yerinden yönetimi, Beşinci Ulusal Yerel Yönetimler Sempozyumu, Türkiye Belediyeler Birliği, Ankara.

Keleş R. ve Yavuz, F. (1989) Yerel yönetimler, genişletilmiş 2. baskı, Ankara: Turhan Kitabevi. 
Tuna ve Bostancı / Mahalli İdarelerde Altyapı Yatırımlarının Finansman Yöntemleri: Ankara Su ve Kanalizasyon İdaresi (ASKİ) Genel Müdürlüğü Örneği / Financial Instruments of Infrastructure Investments in Local Administrations: The Case of Ankara Water and Sewerage Administration (ASKI) General Directorate

Kohn, L., \& Pease, R. (2008). Infrastructure Investing: Key Benefits and Risks. J.P. Morgan Asset Management, 1-8.

Mahalli İdareler Genel Müdürlüğ̈ 2008/31 Sayılı Genelge. https://yerelyonetimler. csb.gov.tr/genelgeler-i-90284 (Erişim Tarihi: 15.02.2021).

Munnell, A.H. (1990). Why has productivity growth declined? productivity and public 1nvestment, New England Economic Review, (January/February), 3-22.

Nadaroğlu, H. (1998). Mahalli idareler (6.baskı). İstanbul: Beta Yayınları.

Nadaroğlu, H. (2001). Mahalli idareler, (yenilenmiş 7.basım). İstanbul: Beta Yayınları.

OECD. (2015). Fostering Investment in Infrastructure. https://www.oecd.org/daf/inv/investment-policy/Fostering-Investment-in-Infrastructure.pdf (Erişim Tarihi: 06.02.2021).

OECD. (2015). Risk and Return Characteistics Of Infrastructure Investment In Low Income Countries.Worldbank, https://www.oecd.org/g 20/topics /develop ment/Report-on-Risk-andReturn-Characteristics-of-Infrastructure investment- in-Low-Income-Countries.pdf. (Erişim Tarihi: 06.02.2021).

Ortaylı, İ. (1982). Osmanlı imparatorluğunda idari modernleşme ve mahalli idare alanındaki gelişmeler, İdare Hukuku ve Ilimler Dergisi (IHHID), Sarıca'ya Armağan, 3(1), 137-148.

Ökmen, M., ve Neslihan, K. (2015). Türkiye'de belediye gelirleri içinde borçlanma ve borçların azaltılması için öneriler. Yönetim ve Ekonomi: Celal Bayar Üniversitesi İktisadi ve İdari Bilimler Fakültesi Dergisi, 22(2), 551-565.

Öncel, S.Y. (1992). Mahalli idareler maliyesi (2.baskı). İstanbul: Filiz Kitabevi.

Özer, M. (2016). Yerel yönetimlerin borçlanma araçları, Gösterge Dergisi, 49-63.

Özkaya Haykır B. (2016). Kamu özel sektör işbirliği sözleşmeleri kapsamındaki fesih ödemesi düzenlemeleri, ülke örnekleri ve Türkiye uygulaması, (Yayımlanmamış Uzmanlık Tezi). Hazine Müsteşarlığı, Ankara.

Seval, Ç. Z. (2013). Türkiye'de desantrilizasyon çabaları çerçevesinde yerel yönetimlerin kamu altyapı yatırımlarınin finansmaninda sermaye piyasasinda yararlanma imkanları, (Yayınlanmış yüksek lisans tezi). Hacettepe Üniversitesi, Ankara.

Snieska, V., \& Zykiene, İ. (2009). Socio-ekonomik impact of infrastructure investments. Engineering Economies, 63(3), 16-25.

Tanrıvermiş, H. (2019). Türkiye ekonomisinde inşaat ve gayrimenkul sektörlerinin rolleri ve gelişme eğilimlerinin değerlendirilmesi, Kent, İnşaat ve Ekonomi Kongresi, 2 TMMOB Mimarlar Odası Gaziantep Şubesi, Gaziantep.

Toprak, Z. (2010). Yerel yönetimler, (8. baskı). İzmir: Birleşik Matbaacılık.

Tortop, N. (1999). Mahalli idareler (6.baskı). Ankara: Yarg1 Yayınları.

Tümer, D. (2019). Mahalli idarelerde mali özerklik ve Türkiye açısından değerlendirilmesi. (Yüksek lisans tezi). Bursa Uludağ Üniversitesi, Sosyal Bilimler Enstitüsü, Maliye Anabilim Dalı Bütçe ve Mali Planlama Bilim Dalı, Bursa.

Türkiye Cumhuriyeti Cumhurbaşkanlığı Strateji ve Bütçe Başkanlığı (2021). https://www.sbb.gov.tr/wp-content/uploads/2018/10/ 10_YerelYone timler.pdf. (Erişim Tarihi: 28.03.2021).

Türkoğlu, İ. (2009). Yerel yönetimlerde mali reform arayıslart: Türkiye'de belediyelerde mali özerklik ve belediye başkanlarının mali özerklik algısl, Ankara: T.C Hazine ve Maliye Bakanlığı Strateji Geliştirme Başkanlığı Yayın No:389, s.10-12. 
Uyar, H. (2004). Türkiye’de ve dünyada yerel yönetimler: kısa bir tarihçe, Aydınlanma 1923 Dergisi. 8(51), 31-38.

Ünal, A. O. (2021). Kamu ulaşım projelerinin gayrimenkul değeri ve kullanımına etkileri: Ankara İli metro projesi örneği, (Doktora Tezi). Ankara Üniversitesi Fen Bilimleri Enstitüsü Gayrimenkul Geliştirme ve Yönetimi Anabilim Dalı, Ankara.

Ünal, A. O. ve Tanrıvermiş, H. (2019). Raylı sistem projelerinin gayrimenkul değerine etkisi: Ankara İli Keçiören İlçesi M4 Metro Hatt1 Projesi örneği, Kastamonu Üniversitesi İktisadi ve İdari Bilimler Fakültesi Dergisi, 21(2), 29-55.

Vural, T. (2015). Özelleştirme kavramının yerel yönetimler açısından değerlendirilmesi, Maliye Araştırmaları Dergisi, 1(1),17-28.

Yaprak, N. (2020). Mahalli idarelerin Türk idare tarihi açısından gelişim süreci ve hizmet sunum yöntemleri, İstanbul Ticaret Üniversitesi Sosyal Bilimler Dergisi, 19(37), 319-341.

5393 Sayılı Belediye Kanunu https://www.mevzuat.gov.tr/MevzuatMetin/1.5.5393.pdf (Erişim Tarihi: 28.03.2021).

4749 Kamu Finansmanı ve Borç Yönetiminin Düzenlenmesi Hakkında Kanun https://www.mevzuat.gov.tr/mevzuat?MevzuatNo=4749\&MevzuatTur=1\&MevzuatTertip=5 (Erişim Tarihi: 28.03.2021).

\section{ETİK ve BİLIMMSEL İLKELER SORUMLULUK BEYANI}

$\mathrm{Bu}$ çalışmanın tüm hazırlanma süreçlerinde etik kurallara ve bilimsel atıf gösterme ilkelerine riayet edildiğini yazar(lar) beyan eder. Aksi bir durumun tespiti halinde Afyon Kocatepe Üniversitesi Sosyal Bilimler Dergisi'nin hiçbir sorumluluğu olmayıp, tüm sorumluluk makale yazarlarına aittir.

\section{ARAŞTIRMACILARIN MAKALEYE KATKI ORANI BEYANI}

1. yazar katk1 oranı : $\% 70$

2. yazar katk1 oran $: \% 30$ 